\title{
MACRO STRESS TEST MODEL RISIKO KREDIT: STUDI EMPIRIS PERBANKAN KONVENSIONAL DAN SYARIAH DI INDONESIA
}

\author{
(A Macro Stress Test Model of Credit Risk: \\ An Empirical Studies of Conventional and Islamic Banking in Indonesia) \\ Indra \\ Sekolah Tinggi Ekonomi Islam Tazkia \\ JI. Ir. H. Djuanda No. 78, Sentul City Bogor, Jawa Barat 16810 \\ Email: indra.steitazkia@gmail.com \\ Naskah diterima: 17 Oktober 2018 \\ Naskah direvisi: 23 Oktober 2018 \\ Naskah diterbitkan: 31 Desember 2018
}

\begin{abstract}
This paper proposes a model to conduct macro-stress tests of credit risk for conventional and Islamic banking in Indonesia based on scenario analysis. The aims are to investigate and to compare the financial system resilience of the two banking systems from various macroeconomic shocks. It used NPL and NPF to measures credit risk of conventional and Islamic banking. It considered several exogenous macroeconomic variables, namely Gross Domestic Product, Exchange Rate, Consumer Price Index, and Interest Rate. It applied the ARDL model which is estimated for each type of bank credit portfolio that splits into 9 sectors. It found that a decreased in GDP, exchange rate depreciation, an increased in CPI, and interest rates contributed to encouraging a rose in both NPL and NPF levels. CPI was the biggest source of vulnerability to credit risk in both groups of banks, followed by GDP, exchange rates, and interest rates. This evidence indicates that the vulnerability of the financial system in both groups of banks did not only depend on the internal performance in each bank but also depend on the external shocks. It also confirmed that although Islamic banks and conventional banks used different operating systems, they could not be separated from macroeconomic shocks.

Keywords: stress test, credit risk, bank, ARDL model, Indonesia
\end{abstract}

\begin{abstract}
Abstrak
Tulisan ini berfokus pada pengembangan model yang mampu melakukan pengujian tekanan makro (macro stress test) terhadap risiko kredit perbankan konvensional dan perbankan syariah di Indonesia dengan menggunakan beberapa analisis skenario. Tujuannya adalah untuk menginvestigasi sekaligus mengkomparasi daya tahan sistem keuangan kedua sistem perbankan tersebut dari berbagai guncangan makro. Variabel risiko kredit yang digunakan adalah NPL untuk perbankan konvensional dan NPF untuk perbankan syariah. Variabel makro eksogenus yang digunakan adalah Produk Domestik Bruto (PDB), kurs, indeks harga konsumen (IHK), dan tingkat suku bunga. Spesifikasi model yang digunakan adalah ARDL, yang diestimasi untuk setiap tipe kredit perbankan yang diklasifikasikan ke dalam 9 (sembilan) sektor dan total seluruh sektor. Studi ini menemukan bahwa, penurunan PDB, depresiasi kurs, kenaikan IHK (inflasi) dan tingkat suku bunga (BI Rate) berkontribusi dalam mendorong kenaikan level NPL maupun NPF. IHK (inflasi) merupakan sumber kerentanan terbesar bagi risiko kredit pada kedua kelompok bank, diikuti oleh PDB, kurs, dan tingkat suku bunga. Fakta ini mengindikasikan bahwa kerentanan sistem keuangan pada kedua kelompok bank tidak hanya bergantung pada kinerja internal pada setiap bank, namun juga dinamika makro eksternal. Hasil ini mengonfirmasi bahwa meski bank syariah dan bank konvensional menggunakan sistem operasi yang berbeda, namun keduanya tidak terlepas dari dinamika ekonomi makro yang terjadi. Kata kunci: stress test, risiko kredit, bank, model ARDL, Indonesia
\end{abstract}

\section{PENDAHULUAN}

Studi-studi yang berfokus pada topik stress testing perbankan telah berkembang cukup pesat dalam beberapa tahun terakhir. Studi-studi tersebut umumnya dilatarbelakangi oleh krisis finansial global yang berimbas pada kolapsnya dunia perbankan di banyak negara. Krisis tersebut telah menimbulkan kesadaran (awareness) akan pentingnya ketahanan sistem keuangan dari berbagai guncangan ekonomi. Tujuan dari stress test pada sektor keuangan adalah untuk memberikan informasi yang memadai mengenai potensi sistem di bawah asumsi guncangan luar biasa (tetapi tetap masuk akal), sehingga dapat membantu policy maker dalam menilai kerentanan sistem keuangan yang ada (Foglia, 2009).
Stress test telah menjadi elemen kunci dari analisis makroprudensial dalam menentukan sensitivitas sistem keuangan dari guncangan ekonomi melalui evaluasi tingkat kesehatan dan kerentanan, yang seringkali didorong oleh eksposur bank-bank akibat risiko ekonomi makro (Jones et al., 2004). Pentingnya stress test untuk analisis makroprudensial berangkat dari fakta bahwa alat ini mampu (i) menyediakan pendekatan yang seragam, sehingga hasilnya dapat diagregasikan, (ii) mengidentifikasi kerentanan kunci pada sistem secara keseluruhan, dan (iii) memberikan informasi mengenai profil risiko yang dapat dikomparasikan dari seluruh bank yang diobservasi (Elsiefy, 2012). 
Stress testing sebagai alat analisis telah menjadi bagian integral dari semua program penilaian kerentanan yang dilakukan oleh bank sentral dan berbagai institusi lainnya, seperti IMF, Bank Dunia, termasuk Bank Indonesia (BI) dan Otoritas Jasa Keuangan (OJK) Indonesia. Dalam konteks ini, stress test sangat penting dari perspektif otoritas pengawas dan pembuat kebijakan. Hal ini karena stress test mampu memberikan informasi yang bermanfaat untuk menilai sistem keuangan secara keseluruhan terhadap berbagai risiko yang mungkin dihadapi. Stress test dapat membantu memberikan pemahaman yang utuh dan mendalam tentang ketahanan sektor perbankan terhadap beberapa skenario tekanan ekonomi makro yang merugikan.

Selama dua dekade terakhir, tercatat dua krisis finansial global pernah menerpa Indonesia, yaitu krisis tahun 1998 dan 2009. Krisis keuangan tahun 1998 di Indonesia dipicu oleh guncangan eksternal melalui nilai tukar yang berdampak terhadap stabilitas perbankan domestik dan berujung pada krisis multi dimensi. Sementara krisis keuangan tahun 2009 (lebih dikenal dengan subprime mortgage) berawal dari permasalahan kegagalan pembayaran kredit perumahan di Amerika Serikat. Krisis kemudian meluas hingga ke Eropa dan Asia. Ketidakstabilan ini menyebabkan efek domino terhadap solvabilitas dan likuiditas lembaga-lembaga keuangan dinegara-negara tersebut. Ketidakstabilan yang terjadi pada sektor keuangan menimbulkan dampak buruk yaitu hilangnya kepercayaan masyarakat pada fungsi intermediasi lembaga keuangan, menurunnya pertumbuhan ekonomi, dan membuat biaya pemulihan akibat krisis menjadi sangat besar. Begitu juga dengan krisis utang negara-negara Eropa dan Amerika Serikat pada tahun 2011, yang sedikit banyak berdampak pada ekspor nasional karena menurunnya kemampuan konsumsi barang impor masyarakat di negara-negara tersebut. Namun demikian, dibandingkan dengan krisis tahun 1998, pada krisis tahun 2009 dan 2011, fundamental ekonomi makro Indonesia masih relatif terjaga.

Krisis keuangan global yang berpotensi memicu krisis sistemik perbankan setidaknya dapat menimbulkan dua konsekuensi. Pertama, efek biaya tinggi, karena peran Bank Sentral sebagai lender of last resort. Pada saat krisis tahun 1998, untuk merestrukturisasi dan mempertahankan beberapa bank tetap beroperasi, Bank Indonesia diperkirakan memberikan suntikan likuiditas lebih dari 50 persen Produk Domestik Bruto (PDB) pada saat itu. Kedua, sebagian besar bank tidak bisa lagi secara efektif melaksanakan fungsi intermediasinya (Nursechafia dan Abduh, 2014). Kedua alasan ini mengindikasikan bahwa mengatasi persoalan instabilitas sektor perbankan yang diakibatkan oleh guncangan eksternal dan internal yang mungkin terjadi mesti menjadi prioritas bagi policy maker. Dalam hal ini, informasi mengenai berbagai indikator yang mencerminkan instabilitas perbankan beserta determinannya mutlak diperlukan.

Dalam konteks Indonesia, sistem perbankan menganut sistem perbankan ganda (dual-banking system) yaitu Bank Konvensional dan BankSyariah. Hal ini diakui dan dikenal sejak diberlakukannya UndangUndang No. 7 Tahun 1992 tentang Perbankan. Kemudian diperkuat dengan adanya Undang-Undang No. 10 tahun 1998 sebagai pengganti Undang-Undang No. 7 Tahun 1992. Penerapan sistem perbankan ganda diharapkan dapat memberikan alternatif transaksi keuangan yang lebih lengkap untuk masyarakat. Penerapan sistem perbankan berganda dapat meningkatkan pembiayaan bagi sektor riil secara bersama-sama antara Bank Syariah dan Bank Konvensional. Sejak berdiri pertama kali pada tahun 1992, Perbankan syariah di Indonesia secara umum telah memperlihatkan perkembangan yang sangat baik. Fakta menunjukkan bahwa dalam satu dekade terakhir, perbankan syariah telah memperlihatkan pertumbuhan yang pesat. Fakta ini terlihat dari meningkatnya aset perbankan syariah dari Rp26,7 triliun pada tahun 2006, menjadi Rp356,5 triliun pada akhir tahun 2016. Sepanjang periode tersebut pertumbuhan aset perbankan syariah secara ratarata mencapai 123,6 persen per tahun, sementara perbankan konvensional hanya mencapai rata-rata 29,7 persen per tahun.

Meski mengalami perkembangan yang cukup baik dalam beberapa waktu terakhir, namun pangsa perbankan syariah masih relatif kecil jika dibandingkan dengan perbankan konvensional. Dari sisi aset, menurut data OJK, pangsa perbankan syariah pada tahun 2016 hanya tercatat sebesar 5,30 persen. Namun demikian, pangsa tersebut tercatat mengalami kenaikan yang cukup signifikan sejak tahun 2006 yang hanya sebesar 1,58 persen. Meski memiliki pangsa yang relatif kecil, namun perbankan syariah memiliki daya tahan lebih baik ketika menghadapi krisis daripada perbankan konvensional. Sebagai gambaran, pada saat krisis ekonomi tahun 1998 di mana kedua bank konvensional dan bank syariah di Indonesia mengalami default kredit yang cukup tinggi yang belum pernah terjadi sebelumnya, di mana diperkirakan masing-masing sebesar 58,7 persen dan 65,61 persen (Bank Indonesia, 1999). Namun, berbeda dengan perbankan konvensional, sistem perbankan syariah mengalami pemulihan dan kemajuan lebih cepat. Misalnya, kinerja dalam hal kualitas aset yang diwakili oleh nonperforming financing (NPF) dilaporkan berada di bawah 5 persen (Bank Indonesia, 2012). 
Namun demikian, meski memiliki ketahanan yang dianggap lebih baik, bukan berarti bank syariah sepenuhnya bebas dari risiko guncangan internal dan eksternal. Salah satu indikator kinerja yang umumnya digunakan untuk mengukur tingkat stabilitas perbankan adalah non-performing loan (NPL) untuk bank konvensional atau non-performing financing (NPF) untuk bank syariah. Tingginya rasio NPL atau NPF mencerminkan potensi ketidakstabilan perbankan. Menurut data Bank Indonesia menemukan bahwa pada kuartal IV tahun 2009, rasio NPF bank syariah di Indonesia pernah berada pada level di atas 5 persen. Menurut Bank Indonesia, rasio NPF yang berada di atas 5 persen dapat mengganggu kesehatan bank. Tingginya rasio NPF manandakan meningkatnya ketidakmampuan debitur untuk membayar pinjaman (default). Default terjadi ketika debitur tidak dapat memenuhi kewajiban kontrak mereka karena beberapa faktor seperti kemerosotan ekonomi. Dengan kata lain, meski filosofi dasar perbankan konvensional dan syariah pada dasarnya berbeda, namun keduanya memiliki risiko yang sama karena keduanya beroperasi dalam lingkungan ekonomi makro yang sama.

Tulisan ini berfokus pada pengembangan model yang mampu melakukan pengujian tekanan makro (macro stress test) terhadap risiko kredit perbankan konvensional dan syariah di Indonesia dengan menggunakan beberapa analisis skenario. Tujuannya adalah untuk menginvestigasi sekaligus mengkomparasi daya tahan sistem keuangan dari kedua sistem perbankan tersebut dari berbagai guncangan makro. Dalam studi ini, pengujian dibatasi pada risiko kredit yang diklasifikasikan berdasarkan sektor ekonomi dan agregat. Untuk perbankan konvensional, variabel risiko kredit yang digunakan adalah NPL, sementara untuk perbankan syariah akan digunakan NPF.

Studi-studi empiris mengenai stress test terhadap sistem keuangan perbankan di berbagai negara telah berkembang cukup pesat. Studi-studi tersebut sebagian besar memfokuskan pada pengujian risiko kredit perbankan. Hal ini karena, meski aktivitas perbankan mengalami kemajuan yang cukup pesat, namun risiko kredit tetap menjadi sumber utama yang memiliki andil bagi risiko perbankan secara keseluruhan. Kerangka kerja yang digunakan untuk melakukan stress test risiko kredit pada studi-studi tersebut cukup bervariasi antarnegara. Menurut Elsiefy (2012), hal ini dikarenakan kondisi spesifik setiap negara dapat bervariasi, seperti kompleksitas sistem perbankan dan ketersediaan data. Beberapa studi tersebut secara ringkas akan disajikan berikut ini.

Froyland and Larsen (2002) melakukan pengujian kerentanan sistem perbankan di Norwegia terhadap perubahan ekonomi makro dalam kerangka stress testing. Pada studi ini, variabel rata-rata kerugian pinjaman (expected loan loss) digunakan sebagai indikator kerentanan perbankan. Kerangka pengujian stress test dilakukan dengan menggunakan dua skenario utama, yaitu penurunan harga rumah dan peningkatan upah. Studi ini menemukan bahwa skenario penurunan harga rumah memiliki dampak yang cukup besar bagi kenaikan losses perbankan. Begitu juga, skenario perbankan.

Hoggarth, et al. (2005) menggunakan model vector autoregressive (VAR) untuk mengestimasi dampak perubahan variabel-variabel ekonomi makro terhadap kerentanan sistem perbankan di UK. Studi ini menggunakan rasio write-off to loans sebagai proksi variabel kerentanan bank. Studi ini menemukan adanya hubungan negatif dan signifikan antara pertumbuhan PDB dengan rasio write-off to loans pada sektor perbankan secara keseluruhan. Secara khusus, studi ini menemukan bahwa rasio write-off to loans cenderung semakin meningkat seiring terjadinya guncangan variabel tingkat inflasi retail tahunan dan tingkat suku bunga nominal. Peningkatan tersebut setidaknya terjadi setelah periode 4 triwulan berjalan.

Oviedo (2003) melakukan investigasi tentang interaksi antara risiko agregat, kerapuhan sistem keuangan, dan kinerja ekonomi makro dan pengaruhnya terhadap risiko kredit yang dihadapi perbankan di negara-negara berkembang. Dalam studi ini disimpulkan bahwa risiko kredit dan krisis perbankan dipicu oleh variabel fundamental dan bukan terjadi dengan sendirinya, stabilitas keuangan dan risiko ekonomi makro mempunyai pengaruh penting terhadap siklus bisnis. Probabilitas seberapa parah kegagalan sistem perbankan secara endogen ditentukan oleh nilai variabel-variabel kinerja ekonomi. Studi ini juga menunjukkan bahwa krisis lebih sering terjadi selama ekonomi mengalami penurunan dan juga seiring dengan kenaikkan tingkat suku bunga. Hasil studi ini mendukung penelitian sebelumnya yang dilakukan oleh Reinhart dan Kaminsky (1999), di mana risiko kredit dipengaruhi oleh siklus kinerja ekonomi dan perubahan tingkat suku bunga.

Misina dan Tessier (2008) menginvestigasi dampak guncangan ekonomi makro terhadap rata-rata losses dari portofolio pinjaman korporat perbankan di Kanada. Dengan menggunakan model VAR studi ini mengukur probabilitas default sektoral terhadap perubahan variabel-variabel ekonomi makro seperti pertumbuhan PDB, tingkat suku bunga, indek harga komoditas, pertumbuhan ekonomi AS, dan tingkat suku bunga AS. Selanjutnya, Glogowski (2008) mengkaji hubungan antara variabel-variabel 
siklus bisnis dan kerugian pinjaman (loan losses) di perbankan Polandia. Dengan menggunakan model regresi data panel, studi ini menemukan bahwa loan losses secara signifikan dipengaruhi oleh pertumbuhan PDB riil, perubahan tingkat suku bunga, dan tingkat pengangguran. Secara khusus studi ini juga menemukan bahwa perbedaan loan losses antar bank dapat dijelaskan melalui adanya perbedaan profil bisnis dan struktur portofolio kredit pada setiap bank. Otani, et al. (2009) melakukan stress test terhahap portofolio kredit perbankan di Jepang. Studi ini mengaplikasikan kerangka stress test yang digunakan oleh Bank of Japan dan menyertakan perubahan kredit peminjam selama siklus bisnis untuk menguji ketahanan portofolio pinjaman pada bank-bank skala besar terhadap kemerosotan ekonomi yang tajam. Model yang digunakan adalah VAR dengan menggunakan lima indikator makro, yaitu PDB riil, IHK, outstanding pinjaman bank, nilai tukar nominal efektif, dan overnight call rate. Secara umum, hasil simulasi studi ini menemukan bahwa terdapat keterkaitan antara risiko kredit dengan terjadinya resesi ekonomi yang cukup mendalam.

Kattai (2010) membangun model risiko kredit untuk sistem perbankan di Estonia. Pada studi ini NPL dan loan loss provisions sektoral digunakan sebagai indikator risiko kredit. Indikator-indikator ekonomi makro yang digunakan adalah pertumbuhan ekonomi, pengangguran, tingkat suku bunga, inflasi, utang, dan pertumbuhan kredit. Studi ini menemukan bahwa pertumbuhan ekonomi merupakan faktor yang berpengaruh dominan terhadap kesehatan perbankan. Vazquez, et al. (2012) melakukan pengujian macro stress test terhadap risiko kredit perbankan di Brazil dengan menggunakan beberapa skenario. Risiko kredit dicerminkan melalui NPL bank yang dikelompokkan ke dalam beberapa sektor ekonomi. Studi ini menemukan adanya perilaku prosiklis yang kuat dari kualitas kredit. Dalam hal ini ditemui adanya hubungan negatif yang kuat antara NPL dan pertumbuhan PDB, di mana respon NPL terhadap pertumbuhan PDB terjadi lebih dari tiga kuartal. Elsiefy (2012) melakukan pengujian ketahanan sektor perbankan di Qatar terhadap guncangan dari tiga jenis risiko: risiko kredit, risiko tingkat suku bunga, dan risiko nilai tukar. Dalam studi ini, bank dikelompokkan menjadi dua berdasarkan model bisnisnya, yaitu 5 (lima) bank konvensional dan 3 (tiga) bank umum syariah. Studi ini mencoba menangkap dampak guncangan-guncangan yang terjadi terhadap setiap kelompok bank dan secara agregat. Studi ini menemukan bahwa secara keseluruhan, risiko sektor perbankan konvensional menurun, dan meningkat untuk perbankan syariah.
Dari berbagai literatur empiris sebelumnya maka dapat dilihat bahwa pengujian stress test di berbagai negara dilakukan dengan menggunakan kerangka model yang cukup bervariasi. Namun demikian, kebanyakan dari studi-studi tersebut menggunakan pemodelan VAR untuk melihat dampak dari berbagai guncangan variabel makro terhadap variabel risiko kredit. Hal ini karena dengan pemodelan VAR, selain mampu mengakomodasi hubungan dinamis antar variabel, juga dimungkinkan untuk melihat pengaruh dari guncangan berbagai variabel makro terhadap variabel risiko kredit yang digunakan. Sementara itu, juga dapat dilihat bahwa berbagai studi empiris tersebut juga menggunakan variabel risiko kredit dan variabel ekonomi makro yang cukup bervariasi. Hal ini karena melalui penerapan model ekonometrika untuk pengujian stress risiko kredit, memungkinkan para peneliti untuk memilih variabel risiko kredit dan variabel ekonomi makro yang sesuai dengan kebutuhan studi dan relevansinya dengan setiap negara yang dikaji.

Di sisi lain, studi mengenai macro stress test terhadap perbankan, terutama perbankan syariah di Indonesia masih sangat terbatas. Sepengetahuan penulis, studi-studi mengenai dampak kondisi ekonomi terhadap risiko kredit perbankan di Indonesia lebih banyak diarahkan untuk menganalisis bagaimana pengaruh antara variabel makro dengan indikator risiko kredit seperti NPF dan NPL, dan belum melakukan analisis simulasi skenario kemungkinan perubahan indikator ekonomi makro secara ekstrim (namun tetap masuk akal) bagi indikator risiko kredit.

Secara khusus, studi ini setidaknya memberikan dua kontribusi terhadap literatur stress testing perbankan di Indonesia. Pertama, studi ini mengeksplorasi portofolio kredit perbankan konvensional dan perbankan syariah menurut tipe kredit yang diklasifikasikan ke dalam sektor-sektor ekonomi. Kedua, berbeda dengan studi-studi empris di banyak negara yang menggunakan kerangka model VAR, studi ini menggunakan model ARDL yang memiliki kemampuan (i) menangkap hubungan dinamis antar variabel dalam jumlah lag yang berbeda, (ii) menganalisis pengaruh dari variabel eksogenus makro dalam perspektif jangka pendek dan jangka panjang, dan (iii) menganalisis sejauh mana tingkat sensitivitas risiko kredit terhadap kondisi ekonomi makro untuk setiap jenis kredit berdasarkan sektor-sektor ekonomi.

Sistematika tulisan ini akan disajikan sebagai berikut: bagian II menyajikan metodologi. Pada bagian ini akan didiskusikan data, spesifikasi model empiris, dan keterkaitan teoritis dengan strategi estimasi. Bagian III akan menyajikan hasil analisis dan diskusi. Bagian terakhir akan menyajikan kesimpulan 
dari temuan utama untuk kepentingan perumusan implikasi kebijakan.

\section{METODE}

Studi ini berfokus pada stress testing indikatorindikator ekonomi makro terhadap risiko kredit perbankan konvensional dan syariah di Indonesia. Tujuannya adalah untuk melihat bagaimana dampak dari perubahan ekonomi (terutama PDB) terhadap risiko kredit dari kedua perbankan tersebut. Di sini variabel risiko kredit dibedakan menurut sistem perbankan. Untuk perbankan konvensional akan digunakan NPL, sementara untuk perbankan syariah akan digunakan NPF. Dalam studi ini, NPF yang digunakan adalah agregat NPF dari Bank Umum Syariah (BUS) dan Unit Usaha Syariah (UUS). Sedangkan kerangka model yang digunakan adalah makro autoregressive distributed lag (ARDL) yang diperkenalkan oleh Pesaran dan Shin (1999), serta Pesaran, Shin, dan Smith (2001). Penggunaan kerangka model ini selain digunakan untuk menganalisis pengaruh jangka pendek dan jangka panjang variabel makro terhadap NPL dan NPF, juga untuk melakukan simulasi stress test dari berbagai skenario perubahan variabel makro yang diasumsikan terhadap NPL dan NPF. Data yang digunakan adalah time series bulanan sepanjang tahun 2008-2016. Meski periode data tersebut mencakup periode krisis keuangan global tahun 2009, namun dalam konteks Indonesia, krisis tersebut tidak berdampak signifikan bagi fundamental perekonomian Indonesia. Hal inilah yang membuat kondisi perbankan nasional tidak mengalami ganguan serius.

Variabel-variabel yang digunakan diklasifikasikan menjadi dua, yaitu pertama, variabelendogenus, yaitu NPL perbankan konvensional dan NPF perbankan syariah. Data NPL dan NPF yang digunakan meliputi pinjaman masing-masing perbankan di 9 (sembilan) sektor ekonomi. Kesembilan sektor ekonomi tersebut adalah (i) pertanian, kehutanan dan sarana pertanian, (ii) pertambangan, (iii) perindustrian, (iv) listrik, gas dan air, (v) konstruksi, (vi) perdagangan, restoran dan hotel, (vii) pengangkutan, pergudangan dan komunikasi, (viii) jasa dunia usaha, dan (ix) jasa sosial/masyarakat. Kedua, variabel eksogenus, terdiri dari PDB, tingkat suku bunga Bank Indonesia (interest rate), nilai tukar rupiah (kurs), dan indeks harga konsumen (IHK).

Model empiris yang digunakan untuk analisis macro stress test risiko perbankan syariah di Indonesia diekspresikan dalam bentuk Autoregression Distributed Lag (ARDL) yang dikembangkan berdasarkan model Varquez, Tabak, dan Soutu (2012):

$$
\begin{aligned}
L_{R K_{i, t}=} & \alpha+\sum_{j=1}^{p} \beta_{i, j} L_{R K_{i, t-j}}+\sum_{j=0}^{q_{1}} \varphi_{1 j} \ln P D B_{t-j}+ \\
& \sum_{j=0}^{q_{2}} \varphi_{2 j} \ln \operatorname{KURS}_{t-j}+\sum_{j=0}^{q_{3}} \varphi_{3 j} \ln I H K_{t-j}+ \\
& \sum_{j=0}^{q_{4}} \varphi_{4 j} \text { BIRATE }_{t-j}+\varepsilon_{t} \ldots \ldots \ldots \ldots \ldots \ldots \ldots \text { (1) }
\end{aligned}
$$

Di mana:

$$
\begin{aligned}
& \text { LRK }_{\mathrm{i}, \mathrm{t}} \quad \text { : Logit RK (Risiko Kredit (RK) } \\
& \text { diukur melalui rasio NPL } \\
& \text { terhadap total pembiayaan } \\
& \text { untuk bank konvensional } \\
& \text { dan rasio NPF terhadap total } \\
& \text { pembiayaan untuk bank } \\
& L R K_{i, t}=\ln \left(\frac{R K_{i, t}}{1-R K_{i, t}}\right)
\end{aligned}
$$

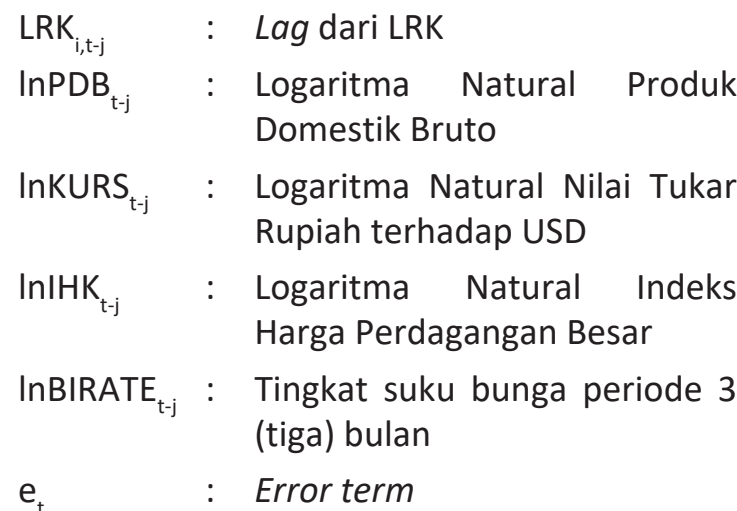

Berdasarkan spesifikasi model (1), selanjutnya dapat ditentukan pengaruh jangka pendek dan jangka panjang dari setiap guncangan variabel eksogen terhadap logit NPL dan logit NPF. Pengaruh jangka panjang dan jangka pendek dari perubahan setiap variabel eksogen terhadap logit NPL dan logit NPF diberikan oleh penjumlahan koefisien estimasi $\varphi_{i}$ dari setiap variabel eksogen. Selanjutnya dengan menggunakan aturan rantai dapat ditentukan pengaruh guncangan setiap variabel eksogenus terhadap untransformed rasio risiko kredit (NPL dan NPF), yang dievaluasi dengan menggunakan rata-rata sampel risiko kredit sebagai berikut:

Dampak Jangka pendek:

$$
\frac{\Delta R K_{i}}{\Delta X_{k}}=\bar{R} K_{i} \times\left(1-\bar{R} K_{i}\right) \times \sum_{q_{k}} \varphi_{k, t-j},
$$

Dampak Jangka panjang:

$$
\frac{\Delta R K_{i}}{\Delta X_{k}}=\frac{1}{1-\beta_{i}} \bar{R} K_{i} \times\left(1-\bar{R} K_{i}\right) \times \sum_{q_{k}} \varphi_{k, t-j}
$$

dengan $X_{k}$ adalah variabel eksogenus ke-k, dan $R K_{i}$ adalah rata-rata risiko kredit (NPL dan NPF) sektor ekonomi ke-i selama periode observasi. 


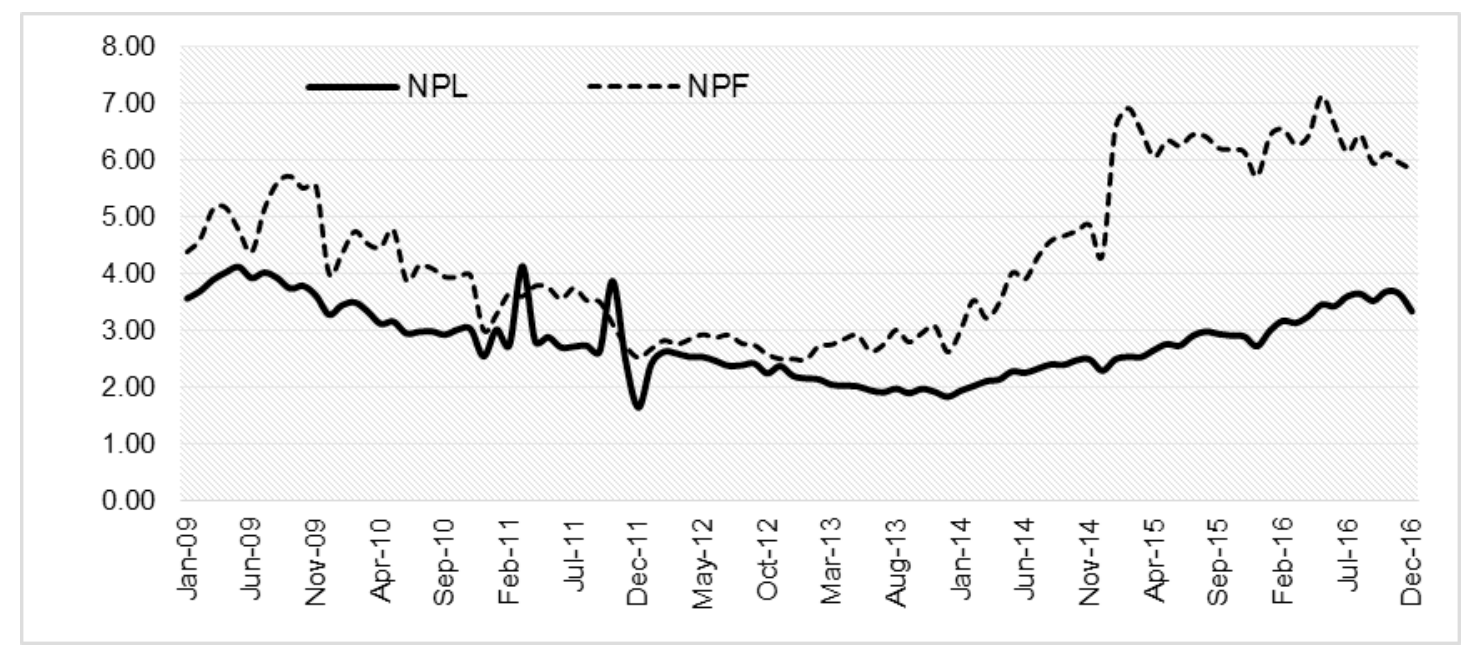

Sumber: Bank Indonesia dan OJK (Diolah).

Gambar 1. Pergerakan NPL dan NPF Tahun 2009-2016

Berdasarkan persamaan (2) dan (3), akan dilakukan simulasi stress test dengan memberikan guncangan (perubahan) terhadap variabel makro eksogenus. Simulasi tersebut dilakukan dengan menggunakan 4 (empat) skenario yang berbeda, yaitu (i) penurunan GDP sebesar 5 persen dari baseline, (ii) depresiasi nilai tukar rupiah terhadap USD10 persen dari baseline, (iii) kenaikan IHK (inflasi) sebesar 10 persen dari baseline, dan (iv) kenaikan tingkat suku bunga sebesar 10 persen dari baseline. Prosedur dan tahapan, serta hasil stress test dalam kerangka 4 (empat) skenario di atas akan dipaparkan pada bahasan selanjutnya.

\section{HASIL DAN PEMBAHASAN \\ Gambaran Umum Risiko Kredit}

Gambar 1 menyajikan pergerakan NPL total kredit bank konvensional dan NPF total kredit bank syariah sepanjang Januari 2009-Desember 2016. Dapat dilihat bahwa pergerakan NPL dan NPF memiliki dua fase yang berbeda selama periode tersebut. Pada kurun waktu Januari 2009-Desember 2011, NPL dan NPF cenderung bergerak menurun, kemudian meningkat kembali hingga akhir tahun 2016. Pergerakan NPL dan NPF meningkat sejak akhir tahun 2011, dapat diasosiasikan dengan krisis utang di Eropa dan Amerika Serikat di tahun 2011 yang sedikit banyak berdampak pada kinerja ekspor nasional. Hal ini pada gilirannya juga berdampak pada kinerja output (PDB) sektoral. Namun demikian, secara umum NPL dan NPF terlihat memiliki pola pergerakan yang sama, yang menunjukkan adanya korelasi positif yang cukup kuat di antara keduanya. Hal ini menjelaskan bahwa dinamika keduanya cenderung dipengaruhi oleh faktor struktural yang sama. Pada Gambar 1 juga dapat dilihat bahwa level NPF cenderung lebih tinggi daripada NPL. Rata-rata NPF selama periode tersebut tercatat sebesar 4,35 persen, dan rata-rata NPL tercatat sebesar 2,82 persen. Fakta ini menandakan bahwa secara umum risiko kredit dari bank syariah cenderung lebih tinggi dari risiko kredit bank konvensional di Indonesia selama periode tersebut.

Tabel 1. Statistik Deskriptif NPL dan NPF Tahun 2009-2016

\begin{tabular}{lccccccccc}
\hline & \multicolumn{3}{c}{ Nektor } & \multicolumn{3}{c}{ Nonvensional } & & \multicolumn{4}{c}{ NPF Syariah } \\
\cline { 2 - 8 } & Mean & Min & Max & CV & Mean & Min & Max & CV \\
\hline Pertanian, kehutanan dan sarana pertanian & 2,19 & 1,43 & 4,53 & 0,33 & 4,91 & 0,94 & 8,73 & 0,34 \\
Pertambangan & 2,23 & 0,30 & 7,34 & 0,75 & 6,26 & 0,68 & 25,62 & 0,86 \\
Perindustrian & 3,47 & 1,71 & 7,73 & 0,44 & 6,40 & 1,35 & 22,24 & 0,73 \\
Listrik, gas dan air & 0,66 & 0,03 & 2,52 & 0,75 & 3,38 & 0,00 & 14,60 & 1,45 \\
Konstruksi & 4,25 & 3,07 & 5,47 & 0,14 & 6,34 & 3,51 & 9,09 & 0,18 \\
Perdagangan, restoran dan hotel & 3,47 & 0,29 & 4,66 & 0,21 & 6,61 & 4,01 & 10,23 & 0,21 \\
Pengangkutan, pergudangan dan komunikasi & 3,06 & 1,76 & 5,69 & 0,31 & 7,22 & 3,15 & 12,12 & 0,31 \\
Jasa dunia usaha & 1,48 & 0,65 & 2,75 & 0,43 & 3,04 & 2,07 & 4,62 & 0,20 \\
Jasa sosial/masyarakat & 3,00 & 1,53 & 5,57 & 0,34 & 4,31 & 1,43 & 12,24 & 0,66 \\
\hline Total & 2,82 & 1,64 & 4,14 & 0,22 & 4,35 & 2,49 & 7,13 & 0,32 \\
\hline
\end{tabular}

Sumber: Bank Indonesia dan OJK (Diolah). 
Tingkat risiko kredit bank syariah yang lebih tinggi daripada bank konvensional tidak hanya terjadi secara agregat, namun juga menurut tipe kredit yang diklasifikasikan ke dalam 9 (sembilan) sektor ekonomi (lihat Tabel 1). Pada kasus bank syariah, tiga sektor dengan risiko kredit (rata-rata NPF) tertinggi adalah pengangkutan, pergudangan, dan komunikasi (7,22 persen), perdagangan, restoran, dan hotel (6,61 persen), dan perindustrian (6,40 persen). Sementara pada kasus bank konvensional, tiga sektor dengan risiko kredit (rata-rata NPL) tertinggi adalah konstruksi $(4,25$ persen), perindustrian $(3,47$ persen), dan perdagangan, restoran, dan hotel $(3,47$ persen). Dapat dilihat bahwa sektor perindustrian dan perdagangan, restoran, dan hotel merupakan sektor dengan tingkat kerentanan risiko kredit yang relatif tinggi, baik pada kasus bank konvensional maupun bank syariah.

Tabel 1 juga menyajikan nilai coefficient of variance $(\mathrm{CV})$ yang mencerminkan tingkat fluktuasi atau volatilitas NPL dan NPF sepanjang Januari 2009 sampai Desember 2016. Dapat dilihat nilai CV NPF ditemui cenderung lebih tinggi dibandingkan nilai CV NPL selama periode tersebut, baik untuk menurut sektor, maupun agregat. Rata-rata nilai CV NPL dan NPF dari total sektor berturut-turut ditemui sebesar 0,22 dan 0,33. Tiga sektor dengan nilai CV NPL tertinggi adalah pertambangan $(0,75)$, listrik, gas dan air $(0,75)$, dan perindustrian $(0,44)$. Sementara tiga sektor dengan nilai CV NPF tertinggi adalah listrik, air, dan gas $(1,45)$, pertambangan $(0,86)$, dan perindustrian $(0,73)$. Fakta ini menjelaskan bahwa secara keseluruhan pergerakan NPF cenderung lebih volatile daripada NPL selama kurun waktu tersebut. Sementara sektor listrik, air, dan gas, pertambangan, dan perindustrian merupakan sektor dengan tingkat volatile risiko kredit tertinggi, baik pada kasus bank konvensional (NPL), maupun bank syariah (NPF).

Relatif lebih tingginya tingkat NPF daripada NPL perlu dimaknai secara hati-hati. Terdapat beberapa faktor yang dapat menyebabkan kondisi tersebut terjadi. Berdasarkan temuan studi Beik dan Arsyianti (2008), dan Husa dan Trinarningsih (2015), alasan yang paling memungkinkan dari relatif tinggi atau naiknya NPF pada bank syariah adalah karena stagnannya pertumbuhan pembiayaan atau terjadi penurunan aset. Rendahnya tingkat pertumbuhan pembiayaan bank syariah dapat dipahami, karena adanya biaya dana (cost of fund) yang relatif tinggi. Hal ini karena bank syariah lebih mengandalkan dana mahal seperti deposito, sehingga bank syariah cenderung memiliki tingkat pembiayaan yang lebih rendah dibanding bank konvensional. Dengan demikian, meski level nominal NPF tidak berubah, atau sedikit meningkat, namun karena pertumbuhan total pembiayaan stagnan, atau aset bank syariah menurun, maka NPF menjadi naik. Dalam konteks ini, peningkatan NPF cenderung terjadi di luar kontrol nasabah. Dengan size perbankan syariah yang masih relatif kecil (dengan market share pada kisaran 5 persen), jika ada sebagian kecil nasabah yang jatuh, maka hal ini akan memengaruhi NPF secara keseluruhan.

\section{Hasil Estimasi Model Risiko Kredit}

Hasil estimasi model risiko kredit (persamaan (1)) dengan menggunakan spesifikasi model ARDL disajikan pada Tabel 1 (untuk NPL) dan Tabel 2 (untuk NPF). Model (1) diestimasi secara berulang untuk setiap tipe kredit, yang diklasifikasikan berdasarkan 9 (sembilan) sektor ekonomi dan total sektor ekonomi. Kesembilan sektor tersebut adalah (1) pertanian, kehutanan dan sarana pertanian, (2) pertambangan, (3) perindustrian, (4) listrik, gas dan air, (5) konstruksi, (6) perdagangan, restoran dan hotel, (7) pengangkutan, pergudangan dan komunikasi, (8) jasa dunia usaha, dan (9) jasa sosial/ masyarakat. Dengan demikian, akan terdapat dua puluh hasil estimasi model yang bebeda, yang terdiri dari 10 (sepuluh) model NPL dan sepuluh model NPF.

Secara umum, hasil estimasi parameter model ARDL untuk model NPL dan NPF terbilang cukup baik. Hal ini diperlihatkan oleh nilai $\mathrm{R}^{2}$ yang berkisar antara 0,31-0,98 untuk model NPL, dan 0,53-0,96 untuk model NPF. Hal yang sama juga diperlihatkan oleh nilai statistik uji $F$ dari seluruh model yang signifikan secara statistik, yang menjelaskan bahwa seluruh variabel bebas yang digunakan di dalam model berpengaruh nyata terhadap NPL dan NPF. Efisiensi dugaan parameter juga terbilang cukup baik, yang diperlihatkan oleh hasil uji autokorelasi Breusch-Godfrey yang ditemui tidak signifikan secara statistik (taraf nyata 5 persen) pada seluruh model. Hal ini menandakan bahwa model terbebas dari masalah autokorelasi. Begitu juga dengan hasil uji White, yang ditemui tidak signifikan (pada taraf nyata 5 persen) pada hampir seluruh model, yang menandakan model telah terbebas dari masalah heteroskedastisitas.

Hasil estimasi parameter, baik pada model NPL (Tabel 1) maupun model NPF (Tabel 2), memiliki koefisien estimasi yang relatif sama. Estimasi parameter lag dependent variable ditemui berkisar antara 0 sd 1, dan hampir seluruhnya signifikan secara statistik (taraf nyata 1-10 persen). Hasil ini menandakan adanya stabilitas dari seluruh model ARDL yang dihasilkan. Dengan hasil ini, dimungkinkan untuk menginvestigasi pengaruh dari setiap variabel makro eksogenus terhadap variabel risiko kredit (NPL dan NPF), baik dalam jangka pendek maupun janga panjang. 
Selanjutnya, hasil estimasi menemukan bahwa koefisien estimasi variabel PDB konsisten bertanda negatif pada seluruh model, serta signifikan pada sebagian besar kasus model, baik pada model NPL maupun NPF. Hasil ini menandakan adanya pengaruh nyata dari penurunan PDB terhadap kenaikan risiko kredit (NPL dan NPF), begitu juga sebaliknya. Hal ini dapat dipahami karena PDB merupakan cerminan dari output atau kinerja perekonomian secara keseluruhan. Menurunnya PDB merupakan indikasi dari menurunnya pendapatan sektor ekonomi secara keseluruhan. Penurunan tersebut dapat berimbas pada penurunan pendapatan dan kemampuan membayar debitur. Hal inilah yang pada gilirannya akan menekan kenaikan NPL dan NPF pada sektor ekonomi secara umum. Temuan ini sejalan dengan beberapa hasil studi empiris, di antaranya Hoggarth, et al. (2005), Misina dan Tessier (2008), Otani, et al. (2009), Kattai (2010), dan Vazquez, et al. (2012) yang menemukan bahwa penurunan tingkat output (PDB) berperan signifikan dalam mendorong kenaikan risiko kredit perbankan.

Di lain pihak, meski sebagian besar koefisien kurs ditemui bertanda positif, namun pada beberapa kasus, koefisien estimasi kurs ditemui bertanda negatif. Pada kasus NPL, koefisien estimasi kurs yang bertanda positif ditemui pada sektor pertanian, kehutanan dan sarana pertanian, pertambangan, perdagangan, restoran dan hotel, jasa dunia usaha, jasa sosial/masyarakat. Sementara pada kasus NPF, koefisien estimasi kurs yang bertanda positif ditemui pada sektor perindustrian, perdagangan, restoran dan hotel, jasa dunia usaha, dan jasa sosial/masyarakat. Sektor-sektor ekonomi yang menghasilkan koefisien estimasi kurs yang bertanda positif menandakan adanya pengaruh depresiasi kurs terhadap kenaikan risiko kredit (NPL dan NPF), begitu juga sebaliknya. Hasil ini juga menjelaskan depresiasi nilai tukar rupiah terhadap USD dapat memberikan tekanan pada beberapa sektor pinjaman, baik pada kasus bank konvensional maupun bank syariah. Namun demikian, relatif bervariasinya dampak depresiasi kurs terhadap sektor-sektor ekonomi mengindikasikan dampak tersebut tidak terlalu dominan terhadap kenaikan risiko kredit perbankan. Hasil ini memperkuat studi Elsiefy (2012) yang menemukan gejala serupa. Menurutnya, relatif kecilnya pengaruh kurs tersebut karena tidak seluruh aset dari kedua kelompok bank tersebut dikelola dalam bentuk mata uang asing, terutama dalam USD.

Hasil estimasi juga memperlihatkan bahwa secara umum, koefisien estimasi IHK bertanda positif dan signifkan pada hampir seluruh model NPL dan NPF, serta signifikan pada beberapa kasus model. Hasil ini menjelaskan bahwa kenaikan IHK diduga berperan dalam meningkatkan risiko kredit baik di bank konvensional (NPL) maupun bank syariah (NPF). Meningkatnya risiko kredit akibat tekanan IHK (inflasi) ini sejalan dengan temuan Hoggart, et al. (2005) dan Kattai (2010). Fakta ini dapat dipahami karena kenaikan harga barang dan jasa secara umum dengan asumsi tingkat pendapatan tidak berubah akan berimplikasi terhadap menurunnya pendapatan rill dan daya beli masyarakat, termasuk para pelaku di sektor-sektor ekonomi secara keseluruhan. Menurunnya pendapatan riil ini pada gilirannya dapat melemahkan kemampuan membayar para debitur dan mendorong peningkatan NPL dan NPF secara keseluruhan.

Selanjutnya, hasil estimasi juga memperlihatkan koefisien estimasi BI Rate bertanda positif dan dan signifikan pada beberapa kasus model, yang menjelaskan bahwa kenaikan $\mathrm{BI}$ Rate cenderung meningkatkan risiko kredit pada kedua jenis bank tesebut. Hasil ini memperkuat temuan beberapa studi empiris terdahulu, di antaranya studi Hoggart, et al. (2005), Kattai (2010), dan Elsiefy (2012). Fakta ini dapat dipahami karena pergerakan tingkat suku bunga Bank Indonesia merupakan cerminan dari dinamika tingkat bunga pinjaman perbankan. Dalam hal ini, kenaikan tingkat suku bunga Bank Indonesia dapat meningkatkan tingkat suku bunga pinjaman perbankan, yang berarti membuat biaya investasi atau biaya pinjaman bagi debitur semakin lebih tinggi. Tingginya bunga pinjaman ini, tanpa diimbangi peningkatan pendapatan debitur yang memadai tentunya dapat meningkatkan beban biaya pengembalian pinjaman. Hal inilah yang kemudian mendorong peningkatan NPL dan NPF pada beberapa sektor ekonomi. 


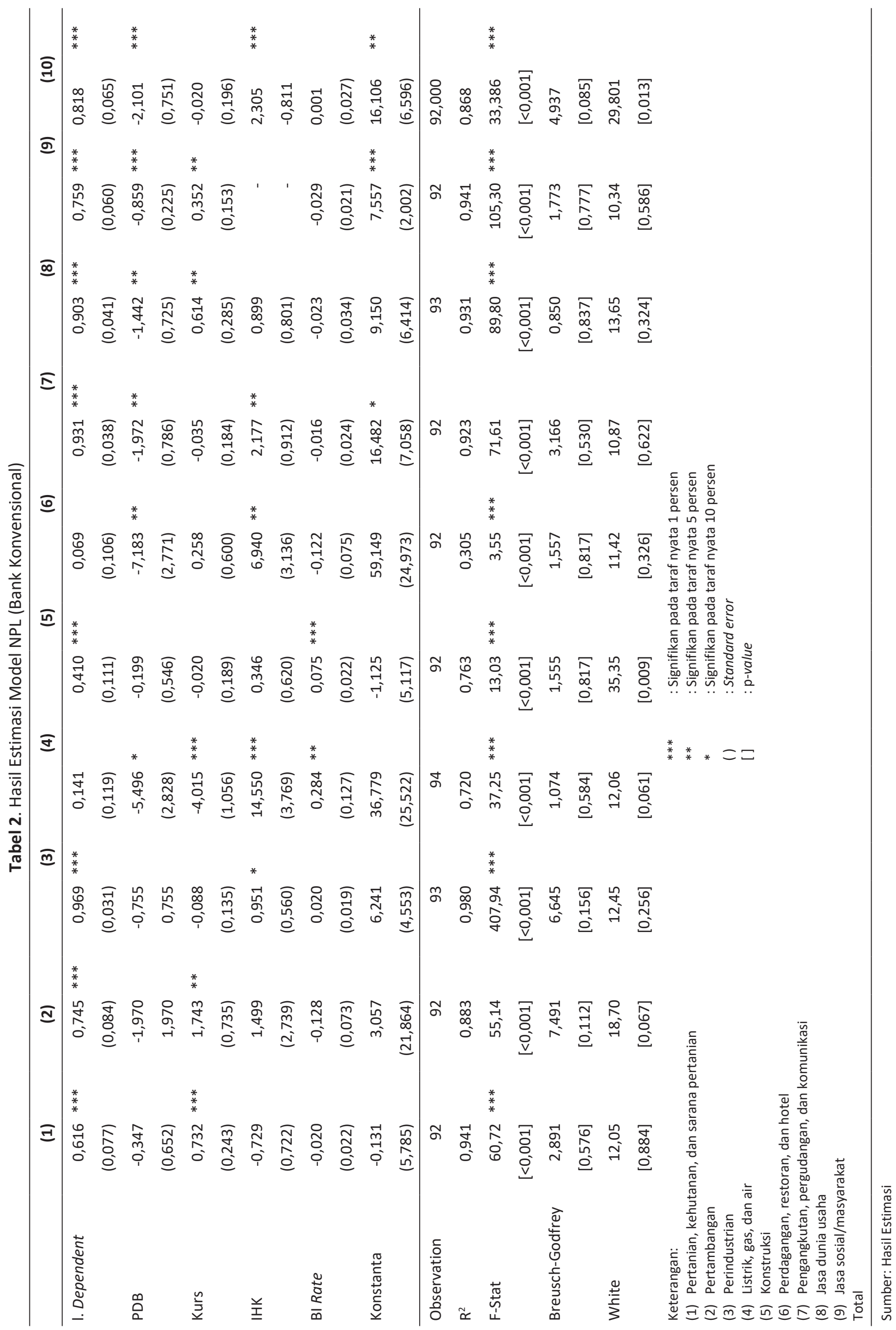




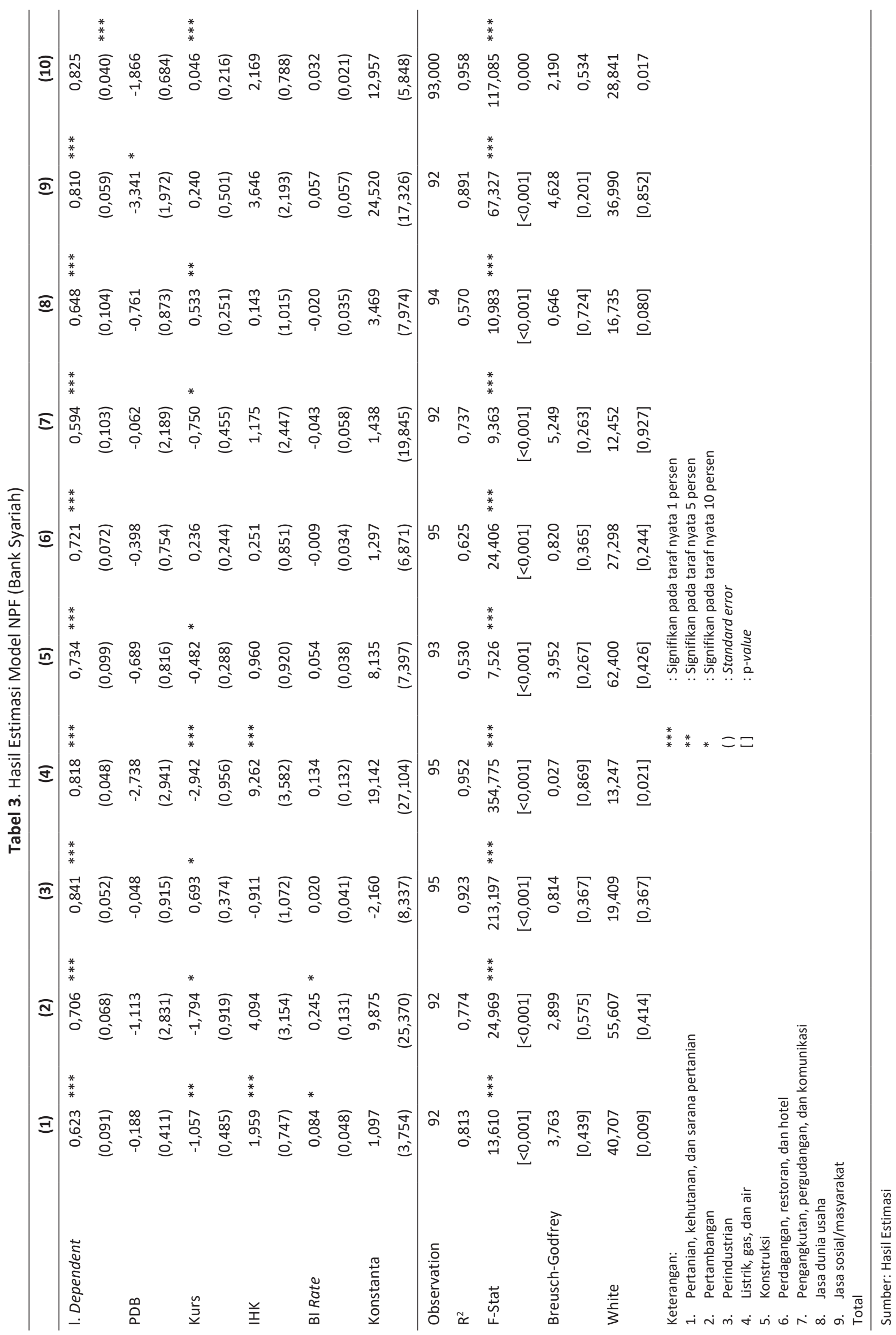




\section{Hasil Simulasi Stress Test}

Hasil simulasi stress test guncangan variabel makro terhadap NPL dan NPF disajikan pada Tabel 3-6. Pada simulasi tersebut, dilakukan 4 (empat) skenario yang berbeda untuk menguji sekaligus mengkomparasi daya tahan NPL dan NPF terhadap guncangan variabel makro. Skenario tersebut adalah (i) penurunan GDP sebesar 5 persen dari baseline, (ii) depresiasi nilai tukar rupiah terhadap USD 10 persen dari baseline, (iii) kenaikan IHK (inflasi) sebesar 10 persen dari baseline, dan (iv) kenaikan tingkat suku bunga sebesar 10 persen dari baseline. Sebagai catatan bahwa besaran angka perubahan dalam keempat skenario tersebut ditentukan secara arbiter. Hal ini karena yang menjadi fokus dalam simulasi adalah untuk menginvestigasi magnitude perubahan dari setiap sektor ekonomi akibat guncangan variabel makro, baik pada kasus NPL maupun NPF. Dalam implementasinya, simulasi dilakukan dengan memanfaatkan hasil estimasi model NPL (Tabel 2) dan NPF (Tabel 3), serta informasi statistik dari NPL dan NPF selama periode Januari 2009-Desember 2016 (Tabel 1).

Selanjutnya, perhitungan simulasi stress test dari berbagai skenario di atas, dilakukan melalui tahapan sebagai berikut (i) menghitung total koefisien estimasi lag variabel dependen NPL dan NPF (kolom (3)), (ii) menghitung total koefisien estimasi setiap variabel makro (kolom (4)), (iii) menghitung pengaruh jangka panjang (long term effect) dari variabel makro (kolom (5)), dengan menggunakan formulasi: (5) = (4)/((1)-(3)), (iv) menghitung scale factor (kolom (6)) dari pengaruh variabel makro dengan menggunakan formulasi: $(6)=(1) \times(1-(1))$, (v) menghitung pengaruh jangka pendek (short term effect) dari perubahan variabel makro (kolom (7)) dari setiap kenario dengan menggunakan formulasi: $(7)=(4) \times(6) \times D X_{i}$, di mana $D X_{i}$ adalah skenario perubahan variabel makro terkait, (vi) menghitung pengaruh jangka panjang (long term effect) dari perubahan variabel makro (kolom (8)) berdasarkan skenario di atas, dengan formulasi: $(8)=(7) /(1-(3))$, (vii) menghitung level perubahan NPL dan NPF dari posisi periode akhir periode observasi (kolom (9)), dan menghitung tingkat kenaikan NPL dan NPF dari posisi akhir periode observasi (kolom (10)) dan dari rata-rata NPL dan NPF sepanjang periode observasi (kolom (11)).

Simulasi skenario penurunan GDP sebesar 5 persen dari baseline, secara umum memberikan dampak pada kenaikan level NPL dan NPF, baik dalam jangka pendek maupun jangka panjang. Dalam jangka panjang penurunan GDP sebesar 5 persen, diperkirakan akan meningkatkan risiko kredit NPL sektoral pada kisaran 1,02-2,21 kali lipat dari posisi akhir observasi (Desember 2016). Tiga sektor yang mengalami kenaikan NPL tertinggi adalah perindustrian atau manufaktur $(2,21)$, pengangkutan, pergudangan, dan komunikasi $(1,89)$, dan jasa dunia usaha $(1,63)$. Sementara itu, dengan skenario yang sama, risiko kredit NPF sektoral diperkirakan naik pada kisaran 1,01-1,74 kali lipat dari posisi akhir observasi (Desember 2016). Secara umum, hasil simulasi skenario penurunan GDP memberikan dampak yang lebih besar bagi kenaikan level NPL daripada NPF. Tabel 4.3a dan 4.3b juga memperlihatkan bahwa level kenaikan total NPL dari posisi akhir observasi dan nilai rata-ratanya dalam jangka panjang mencapai 1,77 dan 2,09 kali lipat, sementara kenaikan total NPF mencapai 1,38 dan 1,85 kali lipat. Temuan ini menjelaskan bahwa NPL relatif lebih rentan terhadap guncangan GDP daripada NPF.

Simulasi skenario depresiasi kurs sebesar 10 persen dari baseline, secara umum memberikan dampak bagi peningkatan NPL dan NPF, baik dalam jangka pendek maupun jangka panjang. Peningkatan NPL terjadi pada 5 (lima) sektor dari 9 (sembilan) sektor tipe kredit yang diobservasi. Dalam jangka panjang, depresiasi kurs sebesar 10 persen, diperkirakan akan meningkatkan risiko kredit NPL dari kelima sektor tersebut pada kisaran 1,02-1,54 kali lipat dari posisi akhir observasi (Desember 2016). Tiga sektor yang mengalami kenaikan NPL tertinggi adalah jasa dunia usaha $(1,54)$, jasa sosial masyarakat $(1,25)$, dan pertambangan $(1,21)$. Sementara itu, dengan skenario yang sama, terdapat 4 (empat sektor) yang mengalami kenaikan level NPF dari posisi akhir observasi. Ketiga sektor dengan kenaikan tertinggi adalah perindustrian (1,39), jasa sosial/ masyarakat $(1,11)$, dan jasa dunia usaha $(1,10)$. Secara umum, pada skenario depresiasi kurs sebesar 10 persen, kenaikan level NPL relatif sama dengan kenaikan level NPF. Tabel 3a dan 3b memperlihatkan bahwa kenaikan total NPL dan NPF dalam jangka panjang dari posisi akhir observasi berturut-turut mencapai 1,05 dan 1,02 kali lipat. Dan kenaikan total NPL dan NPF dalam jangka panjang dari posisi rata-ratanya mencapai 1,24 dan 1,37 kali lipat. Jika dibandingkan dengan posisi akhir periode observasi, terlihat bahwa NPL relatif lebih rentan terhadap guncangan kurs daripada NPF.

Selanjutnya, simulasi skenario kenaikan IHK (inflasi) sebesar 10 persen dari baseline, secara umum berdampak pada peningkatan NPL dan NPF, baik dalam jangka pendek maupun jangka panjang. Kecuali pertanian, kehutanan, dan sarana pertanian, seluruh sektor mengalami kenaikan NPL pada kisaran 1,06-4,05 kali lipat dari posisi akhir periode observasi. Kenaikan ini relatif lebih besar daripada dua skenario sebelumnya. Tiga sektor yang mengalami 
Tabel 3a. Dampak Penurunan GDP 5 Persen terhadap NPL

\begin{tabular}{|c|c|c|c|c|c|c|c|c|c|c|c|}
\hline \multirow{3}{*}{ Sektor } & \multirow{3}{*}{$\begin{array}{c}\begin{array}{c}\text { Average } \\
\text { NPL }\end{array} \\
\text { (1) }\end{array}$} & \multirow{3}{*}{$\begin{array}{c}\text { NPL } \\
\text { Des } \\
2016 \\
(2)\end{array}$} & \multirow{3}{*}{$\begin{array}{l}\text { Coef } \\
\text { Lag } \\
\text { NPL } \\
(3)\end{array}$} & \multirow{3}{*}{$\begin{array}{l}\text { Sum } \\
\text { Coef } \\
\text { GDP } \\
(4)\end{array}$} & \multirow{3}{*}{$\begin{array}{c}\text { Long } \\
\text { Term } \\
\text { Effect }\end{array}$} & \multirow{3}{*}{$\begin{array}{c}\text { Scale } \\
\text { Factor } \\
(6)\end{array}$} & \multicolumn{2}{|c|}{$\begin{array}{l}\text { Increase in } \\
\text { NPL }\end{array}$} & \multicolumn{3}{|c|}{ Stressed NPL } \\
\hline & & & & & & & \multirow{2}{*}{$\begin{array}{c}\begin{array}{c}\text { Short } \\
\text { Term }\end{array} \\
(7)\end{array}$} & \multirow{2}{*}{$\begin{array}{c}\text { Long } \\
\text { Term }\end{array}$} & \multirow{2}{*}{$\begin{array}{l}\text { Level } \\
(9)\end{array}$} & \multicolumn{2}{|c|}{$\begin{array}{c}\text { Time } \\
\text { Increase }\end{array}$} \\
\hline & & & & & & & & & & (10) & (11) \\
\hline $\begin{array}{l}\text { Pertanian, kehutanan dan sarana } \\
\text { pertanian }\end{array}$ & 2,19 & 2,16 & 0,62 & $-0,35$ & $-0,90$ & 0,021 & 0,04 & 0,10 & 2,25 & 1,04 & 1,03 \\
\hline Pertambangan & 2,23 & 7,07 & 0,74 & $-1,97$ & $-7,72$ & 0,022 & 0,21 & 0,84 & 7,91 & 1,12 & 3,55 \\
\hline Perindustrian & 3,47 & 3,36 & 0,97 & $-0,75$ & $-24,22$ & 0,034 & 0,13 & 4,06 & 7,42 & 2,21 & 2,14 \\
\hline Listrik, gas dan air & 0,66 & 1,03 & 0,14 & $-5,50$ & $-6,40$ & 0,007 & 0,18 & 0,21 & 1,24 & 1,20 & 1,89 \\
\hline Konstruksi & 4,25 & 3,88 & 0,41 & $-0,20$ & $-0,34$ & 0,041 & 0,04 & 0,07 & 3,95 & 1,02 & 0,93 \\
\hline Perdagangan, restoran dan hotel & 3,47 & 4,00 & 0,07 & $-7,18$ & $-7,72$ & 0,034 & 1,20 & 1,29 & 5,30 & 1,32 & 1,53 \\
\hline $\begin{array}{l}\text { Pengangkutan, pergudangan dan } \\
\text { komunikasi }\end{array}$ & 3,06 & 4,81 & 0,93 & $-1,97$ & $-28,75$ & 0,030 & 0,29 & 4,27 & 9,08 & 1,89 & 2,96 \\
\hline Jasa dunia usaha & 1,48 & 1,73 & 0,90 & $-1,44$ & $-14,91$ & 0,015 & 0,11 & 1,09 & 2,81 & 1,63 & 1,90 \\
\hline Jasa sosial/masyarakat & 3,00 & 1,73 & 0,76 & $-0,86$ & $-3,57$ & 0,029 & 0,12 & 0,52 & 2,25 & 1,30 & 0,75 \\
\hline Total & 2,82 & 3,34 & 0,87 & $-2,47$ & $-18,63$ & 0,027 & 0,34 & 2,56 & 5,90 & 1,77 & 2,09 \\
\hline
\end{tabular}

Sumber: Hasil Estimasi.

kenaikan NPL tertinggi adalah perindustrian $(4,05)$, Ketiga sektor dengan kenaikan NPF tertinggi adalah pengangkutan, pergudangan, dan komunikasi $(2,96)$, jasa sosial/masyarakat $(2,61)$, listrik, gas, dan air dan listrik, air, dan gas $(2,07)$. Sementara itu, dengan $\quad(2,50)$, dan pertambangan $(1,93)$. Secara umum, hasil skenario yang sama, kecuali sektor perindustrian, simulasi skenario kenaikan IHK sebesar 10 persen seluruh sektor mengalami kenaikan level NPF pada memberikan tekanan yang lebih besar pada NPL kisaran 1,08-2,61 kali lipat dari posisi akhir observasi. daripada NPF. Tabel 4.5a dan 4.5b memperlihatkan

Tabel 3b. Dampak Penurunan GDP 5 Persen terhadap NPF

\begin{tabular}{|c|c|c|c|c|c|c|c|c|c|c|c|}
\hline \multirow{3}{*}{ Sektor } & \multirow{3}{*}{$\begin{array}{c}\text { Average } \\
\text { NPF } \\
\text { (1) }\end{array}$} & \multirow{3}{*}{$\begin{array}{c}\text { NPF } \\
\text { Des } \\
2016 \\
(2)\end{array}$} & \multirow{3}{*}{$\begin{array}{l}\text { Coef } \\
\text { Lag } \\
\text { NPF } \\
(3)\end{array}$} & \multirow{3}{*}{$\begin{array}{l}\text { Sum } \\
\text { Coef } \\
\text { GDP }\end{array}$} & \multirow{3}{*}{$\begin{array}{c}\text { Long } \\
\text { Term } \\
\text { Effect }\end{array}$} & \multirow{3}{*}{$\begin{array}{c}\text { Scale } \\
\text { Factor } \\
(6)\end{array}$} & \multicolumn{2}{|c|}{$\begin{array}{l}\text { Increase in } \\
\quad N P F\end{array}$} & \multicolumn{3}{|c|}{ Stressed NPF } \\
\hline & & & & & & & \multirow{2}{*}{$\begin{array}{c}\text { Short } \\
\text { Term }\end{array}$} & \multirow{2}{*}{$\begin{array}{c}\text { Long } \\
\text { Term }\end{array}$} & \multirow{2}{*}{$\begin{array}{c}\text { Level } \\
(9)\end{array}$} & \multicolumn{2}{|c|}{$\begin{array}{l}\text { Time } \\
\text { Increase }\end{array}$} \\
\hline & & & & & & & & & & (10) & (11) \\
\hline $\begin{array}{l}\text { Pertanian, kehutanan dan sarana } \\
\text { pertanian }\end{array}$ & 4,91 & 4,18 & 0,62 & $-0,19$ & $-0,50$ & 0,047 & 0,04 & 0,12 & 4,29 & 1,03 & 0,87 \\
\hline Pertambangan & 6,26 & 8,75 & 0,71 & $-1,11$ & $-3,79$ & 0,059 & 0,33 & 1,11 & 9,87 & 1,13 & 1,58 \\
\hline Perindustrian & 6,40 & 6,76 & 0,84 & $-0,05$ & $-0,30$ & 0,060 & 0,01 & 0,09 & 6,86 & 1,01 & 1,07 \\
\hline Listrik, gas dan air & 3,38 & 11,10 & 0,82 & $-2,74$ & $-15,06$ & 0,033 & 0,45 & 2,46 & 13,55 & 1,22 & 4,01 \\
\hline Konstruksi & 6,34 & 3,51 & 0,73 & $-0,69$ & $-2,59$ & 0,059 & 0,20 & 0,77 & 4,28 & 1,22 & 0,67 \\
\hline Perdagangan, restoran dan hotel & 6,61 & 6,66 & 0,72 & $-0,40$ & $-1,43$ & 0,062 & 0,12 & 0,44 & 7,10 & 1,07 & 1,07 \\
\hline $\begin{array}{l}\text { Pengangkutan, pergudangan dan } \\
\text { komunikasi }\end{array}$ & 7,22 & 5,17 & 0,59 & $-0,06$ & $-0,15$ & 0,067 & 0,02 & 0,05 & 5,22 & 1,01 & 0,72 \\
\hline Jasa dunia usaha & 3,04 & 4,60 & 0,65 & $-0,76$ & $-2,16$ & 0,029 & 0,11 & 0,32 & 4,91 & 1,07 & 1,62 \\
\hline Jasa sosial/masyarakat & 4,31 & 4,92 & 0,81 & $-3,34$ & $-17,61$ & 0,041 & 0,69 & 3,63 & 8,54 & 1,74 & 1,98 \\
\hline Total & 4,35 & 5,85 & 0,83 & $-1,87$ & $-10,68$ & 0,042 & 0,39 & 2,22 & 8,07 & 1,38 & 1,85 \\
\hline
\end{tabular}

Sumber: Hasil Estimasi. 
Tabel 4a. Dampak Depresiasi Kurs 10 Persen terhadap NPL

\begin{tabular}{|c|c|c|c|c|c|c|c|c|c|c|c|}
\hline \multirow{3}{*}{ Sektor } & \multirow{3}{*}{$\begin{array}{c}\text { Average } \\
\text { NPL } \\
\text { (1) }\end{array}$} & \multirow{3}{*}{$\begin{array}{c}\text { NPL } \\
\text { Des } \\
2016 \\
(2)\end{array}$} & \multirow{3}{*}{$\begin{array}{l}\text { Coef } \\
\text { Lag } \\
\text { NPL } \\
(3)\end{array}$} & \multirow{3}{*}{$\begin{array}{l}\begin{array}{l}\text { Sum } \\
\text { Coef } \\
\text { Kurs }\end{array} \\
(4)\end{array}$} & \multirow{3}{*}{$\begin{array}{c}\text { Long } \\
\text { Term } \\
\text { Effect }\end{array}$} & \multirow{3}{*}{$\begin{array}{c}\text { Scale } \\
\text { Factor } \\
(6)\end{array}$} & \multicolumn{2}{|c|}{$\begin{array}{l}\text { Increase in } \\
\quad \text { NPL }\end{array}$} & \multicolumn{3}{|c|}{ Stressed NPL } \\
\hline & & & & & & & \multirow{2}{*}{$\begin{array}{c}\text { Short } \\
\text { Term }\end{array}$} & \multirow{2}{*}{$\begin{array}{c}\text { Long } \\
\text { Term }\end{array}$} & \multirow{2}{*}{$\begin{array}{c}\text { Level } \\
\text { (9) }\end{array}$} & \multicolumn{2}{|c|}{$\begin{array}{c}\text { Time } \\
\text { Increase }\end{array}$} \\
\hline & & & & & & & & & & (10) & (11) \\
\hline $\begin{array}{l}\text { Pertanian, kehutanan dan sarana } \\
\text { pertanian }\end{array}$ & 2,19 & 2,16 & 0,62 & 0,73 & 1,90 & 0,021 & 0,16 & 0,41 & 2,57 & 1,19 & 1,17 \\
\hline Pertambangan & 2,23 & 7,07 & 0,74 & 1,74 & 6,83 & 0,022 & 0,38 & 1,49 & 8,56 & 1,21 & 3,84 \\
\hline Perindustrian & 3,47 & 3,36 & 0,97 & $-0,09$ & $-2,84$ & 0,034 & $-0,03$ & $-0,95$ & 2,41 & 0,72 & 0,69 \\
\hline Listrik, gas dan air & 0,66 & 1,03 & 0,14 & $-4,01$ & $-4,68$ & 0,007 & $-0,26$ & $-0,31$ & 0,73 & 0,70 & 1,10 \\
\hline Konstruksi & 4,25 & 3,88 & 0,41 & $-0,02$ & $-0,03$ & 0,041 & $-0,01$ & $-0,01$ & 3,87 & 1,00 & 0,91 \\
\hline Perdagangan, restoran dan hotel & 3,47 & 4,00 & 0,07 & 0,26 & 0,28 & 0,034 & 0,09 & 0,09 & 4,10 & 1,02 & 1,18 \\
\hline $\begin{array}{l}\text { Pengangkutan, pergudangan dan } \\
\text { komunikasi }\end{array}$ & 3,06 & 4,81 & 0,93 & $-0,04$ & $-0,51$ & 0,030 & $-0,01$ & $-0,15$ & 4,66 & 0,97 & 1,52 \\
\hline Jasa dunia usaha & 1,48 & 1,73 & 0,90 & 0,61 & 6,35 & 0,015 & 0,09 & 0,93 & 2,65 & 1,54 & 1,79 \\
\hline Jasa sosial/masyarakat & 3,00 & 1,73 & 0,76 & 0,35 & 1,46 & 0,029 & 0,10 & 0,43 & 2,16 & 1,25 & 0,72 \\
\hline Total & 2,82 & 3,34 & 0,87 & 0,08 & 0,63 & 0,027 & 0,02 & 0,17 & 3,51 & 1,05 & 1,24 \\
\hline
\end{tabular}

Sumber: Hasil Estimasi.

bahwa kenaikan total NPL dari posisi akhir observasi dan rata-ratanya dalam jangka panjang mencapai 2,60 dan 3,08 kali lipat. Sementara kenaikan total NPF mencapai 1,88 dan 2,53 kali lipat. Fakta ini juga menjelaskan bahwa NPL lebih rentan terhadap guncangan IHK daripada NPF.
Terakhir, simulasi skenario kenaikan tingkat suku bunga ( $\mathrm{BI}$ Rate) sebesar 10 persen dari baseline, meski tidak sebesar kasus tiga skenario sebelumnya, namun secara umum memberikan dampak bagi peningkatan NPL dan NPF pada beberapa sektor pinjaman, baik dalam jangka pendek maupun jangka panjang. Pada

Tabel 4b. Dampak Depresiasi Kurs 10 Persen terhadap NPF

\begin{tabular}{|c|c|c|c|c|c|c|c|c|c|c|c|}
\hline \multirow{3}{*}{ Sektor } & \multirow{3}{*}{$\begin{array}{c}\text { Average } \\
\text { NPF }\end{array}$} & \multirow{3}{*}{$\begin{array}{c}\text { NPF } \\
\text { Des } \\
2016 \\
(2)\end{array}$} & \multirow{3}{*}{$\begin{array}{l}\text { Coef } \\
\text { Lag } \\
\text { NPF } \\
(3)\end{array}$} & \multirow{3}{*}{$\begin{array}{c}\text { Sum } \\
\text { Coef } \\
\text { Kurs }\end{array}$} & \multirow{3}{*}{$\begin{array}{c}\text { Long } \\
\text { Term } \\
\text { Effect }\end{array}$} & \multirow{3}{*}{$\begin{array}{c}\text { Scale } \\
\text { Factor } \\
(6)\end{array}$} & \multicolumn{2}{|c|}{$\begin{array}{l}\text { Increase in } \\
\quad \text { NPF }\end{array}$} & \multicolumn{3}{|c|}{ Stressed NPF } \\
\hline & & & & & & & \multirow{2}{*}{$\begin{array}{c}\text { Short } \\
\text { Term }\end{array}$} & \multirow{2}{*}{$\begin{array}{c}\text { Long } \\
\text { Term }\end{array}$} & \multirow{2}{*}{$\begin{array}{c}\text { Level } \\
(9)\end{array}$} & \multicolumn{2}{|c|}{$\begin{array}{l}\text { Time } \\
\text { Increase }\end{array}$} \\
\hline & & & & & & & & & & (10) & (11) \\
\hline $\begin{array}{l}\text { Pertanian, kehutanan dan sarana } \\
\text { pertanian }\end{array}$ & 4,91 & 4,18 & 0,62 & $-1,06$ & $-2,81$ & 0,047 & $-0,49$ & $-1,31$ & 2,87 & 0,69 & 0,58 \\
\hline Pertambangan & 6,26 & 8,75 & 0,71 & $-1,79$ & $-6,11$ & 0,059 & $-1,05$ & $-3,59$ & 5,17 & 0,59 & 0,83 \\
\hline Perindustrian & 6,40 & 6,76 & 0,84 & 0,69 & 4,35 & 0,060 & 0,42 & 2,61 & 9,37 & 1,39 & 1,46 \\
\hline Listrik, gas dan air & 3,38 & 11,10 & 0,82 & $-2,94$ & $-16,19$ & 0,033 & $-0,96$ & $-5,28$ & 5,81 & 0,52 & 1,72 \\
\hline Konstruksi & 6,34 & 3,51 & 0,73 & $-0,48$ & $-1,81$ & 0,059 & $-0,29$ & $-1,08$ & 2,43 & 0,69 & 0,38 \\
\hline Perdagangan, restoran dan hotel & 6,61 & 6,66 & 0,72 & 0,24 & 0,84 & 0,062 & 0,15 & 0,52 & 7,18 & 1,08 & 1,09 \\
\hline $\begin{array}{l}\text { Pengangkutan, pergudangan dan } \\
\text { komunikasi }\end{array}$ & 7,22 & 5,17 & 0,59 & $-0,75$ & $-1,85$ & 0,067 & $-0,50$ & $-1,24$ & 3,94 & 0,76 & 0,55 \\
\hline Jasa dunia usaha & 3,04 & 4,60 & 0,65 & 0,53 & 1,51 & 0,029 & 0,16 & 0,45 & 5,04 & 1,10 & 1,66 \\
\hline Jasa sosial/masyarakat & 4,31 & 4,92 & 0,81 & 0,24 & 1,27 & 0,041 & 0,10 & 0,52 & 5,44 & 1,11 & 1,26 \\
\hline Total & 4,35 & 5,85 & 0,83 & 0,05 & 0,26 & 0,042 & 0,02 & 0,11 & 5,96 & 1,02 & 1,37 \\
\hline
\end{tabular}

Sumber: Hasil Estimasi. 
Tabel 5a. Dampak Kenaikan IHK Kurs 10 Persen terhadap NPL

\begin{tabular}{|c|c|c|c|c|c|c|c|c|c|c|c|}
\hline \multirow{3}{*}{ Sektor } & \multirow{3}{*}{$\begin{array}{c}\text { Average } \\
\text { NPL } \\
(1)\end{array}$} & \multirow{3}{*}{$\begin{array}{c}\text { NPL } \\
\text { Des } \\
2016 \\
(2)\end{array}$} & \multirow{3}{*}{$\begin{array}{l}\text { Coef } \\
\text { Lag } \\
\text { NPL } \\
(3)\end{array}$} & \multirow{3}{*}{$\begin{array}{l}\text { Sum } \\
\text { Coef } \\
\text { IHK }\end{array}$} & \multirow{3}{*}{$\begin{array}{c}\text { Long } \\
\text { Term } \\
\text { Effect }\end{array}$} & \multirow{3}{*}{$\begin{array}{c}\text { Scale } \\
\text { Factor } \\
(6)\end{array}$} & \multicolumn{2}{|c|}{$\begin{array}{l}\text { Increase in } \\
\quad N P L\end{array}$} & \multicolumn{3}{|c|}{ Stressed NPL } \\
\hline & & & & & & & \multirow{2}{*}{$\begin{array}{c}\text { Short } \\
\text { Term }\end{array}$} & \multirow{2}{*}{$\begin{array}{c}\text { Long } \\
\text { Term }\end{array}$} & \multirow{2}{*}{$\begin{array}{c}\text { Level } \\
(9)\end{array}$} & \multicolumn{2}{|c|}{$\begin{array}{c}\text { Time } \\
\text { Increase }\end{array}$} \\
\hline & & & & & & & & & & (10) & (11) \\
\hline $\begin{array}{l}\text { Pertanian, kehutanan dan sarana } \\
\text { pertanian }\end{array}$ & 2,19 & 2,16 & 0,62 & $-0,73$ & $-1,90$ & 0,021 & $-0,16$ & $-0,41$ & 1,75 & 0,81 & 0,80 \\
\hline Pertambangan & 2,23 & 7,07 & 0,74 & 1,50 & 5,88 & 0,022 & 0,33 & 1,28 & 8,35 & 1,18 & 3,75 \\
\hline Perindustrian & 3,47 & 3,36 & 0,97 & 0,95 & 30,51 & 0,034 & 0,32 & 10,23 & 13,59 & 4,05 & 3,91 \\
\hline Listrik, gas dan air & 0,66 & 1,03 & 0,14 & 14,55 & 16,95 & 0,007 & 0,95 & 1,11 & 2,15 & 2,07 & 3,25 \\
\hline Konstruksi & 4,25 & 3,88 & 0,41 & 0,35 & 0,59 & 0,041 & 0,14 & 0,24 & 4,12 & 1,06 & 0,97 \\
\hline Perdagangan, restoran dan hotel & 3,47 & 4,00 & 0,07 & 6,94 & 7,45 & 0,034 & 2,33 & 2,50 & 6,50 & 1,62 & 1,87 \\
\hline $\begin{array}{l}\text { Pengangkutan, pergudangan dan } \\
\text { komunikasi }\end{array}$ & 3,06 & 4,81 & 0,93 & 2,18 & 31,73 & 0,030 & 0,65 & 9,43 & 14,24 & 2,96 & 4,65 \\
\hline Jasa dunia usaha & 1,48 & 1,73 & 0,90 & 0,90 & 9,29 & 0,015 & 0,13 & 1,36 & 3,08 & 1,79 & 2,08 \\
\hline Total & 2,82 & 3,34 & 0,87 & 2,59 & 19,52 & 0,027 & 0,71 & 5,36 & 8,70 & 2,60 & 3,08 \\
\hline
\end{tabular}

Sumber: Hasil Estimasi.

skenario ini, diperkirakan hanya terdapat 3 (tiga) level NPF dari posisi akhir observasi. Terdapat 7 sektor yang mengalami kenaikan NPL dari posisi (tujuh) sektor yang mengalami kenaikan level NPF akhir periode observasinya. Namun jika dikomparasi dari posisi rata-ratanya (lihat Tabel 6b). Meskipun dengan rata-rata seluruh periode observasi, terdapat tidak sebesar tiga skenario sebelumnya, kenaikan BI 6 (enam) sektor yang mengalami kenaikan NPL (lihat Rate secara umum memberikan tekanan pada NPL Tabel 6a). Sementara itu, dengan skenario yang dan NPF. Berbeda dengan tiga skenario sebelumnya, sama, kecuali sektor pengangkutan, pergudangan, pada skenario ini, justru NPF yang mengalam level dan transportasi, seluruh sektor mengalami kenaikan kenaikan yang lebih tinggi daripada NPL.

Tabel 5b. Dampak Kenaikan IHK 10 Persen terhadap NPF

\begin{tabular}{|c|c|c|c|c|c|c|c|c|c|c|c|}
\hline \multirow{3}{*}{ Sektor } & \multirow{3}{*}{$\begin{array}{c}\text { Average } \\
\text { NPF }\end{array}$} & \multirow{3}{*}{$\begin{array}{c}\text { NPF } \\
\text { Des } \\
2016 \\
(2)\end{array}$} & \multirow{3}{*}{$\begin{array}{l}\text { Coef } \\
\text { Lag } \\
\text { NPF } \\
(3)\end{array}$} & \multirow{3}{*}{$\begin{array}{c}\text { Sum } \\
\text { Coef } \\
\text { IHK }\end{array}$} & \multirow{3}{*}{$\begin{array}{c}\text { Long } \\
\text { Term } \\
\text { Effect }\end{array}$} & \multirow{3}{*}{$\begin{array}{c}\begin{array}{c}\text { Scale } \\
\text { Factor }\end{array} \\
(6)\end{array}$} & \multicolumn{2}{|c|}{$\begin{array}{c}\text { Increase in } \\
\text { NPF }\end{array}$} & \multicolumn{3}{|c|}{ Stressed NPF } \\
\hline & & & & & & & \multirow{2}{*}{$\begin{array}{c}\text { Short } \\
\text { Term }\end{array}$} & \multirow{2}{*}{$\begin{array}{c}\text { Long } \\
\text { Term }\end{array}$} & \multirow{2}{*}{$\begin{array}{c}\text { Level } \\
(9)\end{array}$} & \multicolumn{2}{|c|}{$\begin{array}{l}\text { Time } \\
\text { Increase }\end{array}$} \\
\hline & & & & & & & & & & (10) & (11) \\
\hline $\begin{array}{l}\text { Pertanian, kehutanan dan sarana } \\
\text { pertanian }\end{array}$ & 4,91 & 4,18 & 0,62 & 1,96 & 5,20 & 0,047 & 0,91 & 2,43 & 6,60 & 1,58 & 1,34 \\
\hline Pertambangan & 6,26 & 8,75 & 0,71 & 4,09 & 13,94 & 0,059 & 2,40 & 8,18 & 16,94 & 1,93 & 2,70 \\
\hline Perindustrian & 6,40 & 6,76 & 0,84 & $-0,91$ & $-5,72$ & 0,060 & $-0,55$ & $-3,42$ & 3,34 & 0,49 & 0,52 \\
\hline Listrik, gas dan air & 3,38 & 11,10 & 0,82 & 9,26 & 50,96 & 0,033 & 3,02 & 16,62 & 27,72 & 2,50 & 8,21 \\
\hline Konstruksi & 6,34 & 3,51 & 0,73 & 0,96 & 3,61 & 0,059 & 0,57 & 2,14 & 5,65 & 1,61 & 0,89 \\
\hline Perdagangan, restoran dan hotel & 6,61 & 6,66 & 0,72 & 0,25 & 0,90 & 0,062 & 0,16 & 0,56 & 7,22 & 1,08 & 1,09 \\
\hline $\begin{array}{l}\text { Pengangkutan, pergudangan dan } \\
\text { komunikasi }\end{array}$ & 7,22 & 5,17 & 0,59 & 1,17 & 2,89 & 0,067 & 0,79 & 1,94 & 7,11 & 1,37 & 0,98 \\
\hline Jasa dunia usaha & 3,04 & 4,60 & 0,65 & 0,14 & 0,40 & 0,029 & 0,04 & 0,12 & 4,72 & 1,03 & 1,55 \\
\hline Jasa sosial/masyarakat & 4,31 & 4,92 & 0,81 & 3,65 & 19,21 & 0,041 & 1,50 & 7,92 & 12,83 & 2,61 & 2,98 \\
\hline Total & 4,35 & 5,85 & 0,83 & 2,17 & 12,41 & 0,042 & 0,90 & 5,16 & 11,01 & 1,88 & 2,53 \\
\hline
\end{tabular}

Sumber: Hasil Estimasi. 
Tabel 6a. Dampak Kenaikan BI Rate 10 Persen terhadap NPL

\begin{tabular}{|c|c|c|c|c|c|c|c|c|c|c|c|}
\hline \multirow{3}{*}{ Sektor } & \multirow{3}{*}{$\begin{array}{c}\text { Average } \\
\text { NPL }\end{array}$} & \multirow{3}{*}{$\begin{array}{c}\text { NPL } \\
\text { Des } \\
2016 \\
(2)\end{array}$} & \multirow{3}{*}{$\begin{array}{l}\text { Coef } \\
\text { Lag } \\
\text { NPL } \\
(3)\end{array}$} & \multirow{3}{*}{$\begin{array}{c}\begin{array}{c}\text { Sum } \\
\text { Coef } \\
\text { BI } \\
\text { Rate }\end{array} \\
(4)\end{array}$} & \multirow{3}{*}{$\begin{array}{c}\text { Long } \\
\text { Term } \\
\text { Effect }\end{array}$} & \multirow{3}{*}{$\begin{array}{c}\text { Scale } \\
\text { Factor } \\
(6)\end{array}$} & \multicolumn{2}{|c|}{$\begin{array}{l}\text { Increase in } \\
\quad N P L\end{array}$} & \multicolumn{3}{|c|}{ Stressed NPL } \\
\hline & & & & & & & \multirow{2}{*}{$\begin{array}{c}\text { Short } \\
\text { Term }\end{array}$} & \multirow{2}{*}{$\begin{array}{c}\begin{array}{c}\text { Long } \\
\text { Term }\end{array} \\
(8)\end{array}$} & \multirow{2}{*}{$\begin{array}{c}\text { Level } \\
\text { (9) }\end{array}$} & \multicolumn{2}{|c|}{$\begin{array}{c}\text { Time } \\
\text { Increase }\end{array}$} \\
\hline & & & & & & & & & & (10) & (11) \\
\hline $\begin{array}{l}\text { Pertanian, kehutanan dan sarana } \\
\text { pertanian }\end{array}$ & 2,19 & 2,16 & 0,62 & $-0,02$ & $-0,05$ & 0,021 & 0,00 & $-0,01$ & 2,15 & 0,99 & 0,98 \\
\hline Pertambangan & 2,23 & 7,07 & 0,74 & $-0,13$ & $-0,50$ & 0,022 & $-0,03$ & $-0,11$ & 6,96 & 0,98 & 3,12 \\
\hline Perindustrian & 3,47 & 3,36 & 0,97 & 0,02 & 0,64 & 0,034 & 0,01 & 0,21 & 3,57 & 1,06 & 1,03 \\
\hline Listrik, gas dan air & 0,66 & 1,03 & 0,14 & 0,28 & 0,33 & 0,007 & 0,02 & 0,02 & 1,06 & 1,02 & 1,60 \\
\hline Konstruksi & 4,25 & 3,88 & 0,41 & 0,07 & 0,13 & 0,041 & 0,03 & 0,05 & 3,93 & 1,01 & 0,92 \\
\hline Perdagangan, restoran dan hotel & 3,47 & 4,00 & 0,07 & $-0,12$ & $-0,13$ & 0,034 & $-0,04$ & $-0,04$ & 3,96 & 0,99 & 1,14 \\
\hline $\begin{array}{l}\text { Pengangkutan, pergudangan dan } \\
\text { komunikasi }\end{array}$ & 3,06 & 4,81 & 0,93 & $-0,02$ & $-0,24$ & 0,030 & 0,00 & $-0,07$ & 4,74 & 0,99 & 1,55 \\
\hline Jasa dunia usaha & 1,48 & 1,73 & 0,90 & $-0,02$ & $-0,24$ & 0,015 & 0,00 & $-0,03$ & 1,69 & 0,98 & 1,14 \\
\hline Jasa sosial/masyarakat & 3,00 & 1,73 & 0,76 & $-0,03$ & $-0,12$ & 0,029 & $-0,01$ & $-0,03$ & 1,70 & 0,98 & 0,57 \\
\hline Total & 2,82 & 3,34 & 0,82 & $-0,023$ & $-0,13$ & 0,027 & $-0,01$ & $-0,03$ & 3,30 & 0,990 & 1,17 \\
\hline
\end{tabular}

Sumber: Hasil Estimasi.

\section{KESIMPULAN}

Tulisan ini berfokus pada pengembangan model yang mampu melakukan pengujian tekanan makro (macro stress test) terhadap risiko kredit perbankan konvensional dan perbankan syariah di Indonesia dengan menggunakan beberapa analisis skenario.
Tujuannya adalah untuk menginvestigasi sekaligus mengkomparasi daya tahan sistem keuangan kedua sistem perbankan tersebut dari berbagai guncangan makro. Dalam studi ini, pengujian dibatasi pada risiko kredit yang diklasifikasikan berdasarkan sektor ekonomi. Untuk perbankan konvensional, variabel

Tabel 6b. Dampak Kenaikan BI Rate 10 Persen terhadap NPF

\begin{tabular}{|c|c|c|c|c|c|c|c|c|c|c|c|}
\hline \multirow{3}{*}{ Sektor } & \multirow{3}{*}{$\begin{array}{c}\text { Average } \\
\text { NPF } \\
(1)\end{array}$} & \multirow{3}{*}{$\begin{array}{c}\text { NPF } \\
\text { Des } \\
2016 \\
(2)\end{array}$} & \multirow{3}{*}{$\begin{array}{c}\text { Coef } \\
\text { Lag } \\
\text { NPF } \\
(3)\end{array}$} & \multirow{3}{*}{$\begin{array}{c}\text { Sum } \\
\text { Coef } \\
\text { BI } \\
\text { Rate }\end{array}$} & \multirow{3}{*}{$\begin{array}{c}\text { Long } \\
\text { Term } \\
\text { Effect }\end{array}$} & \multirow{3}{*}{$\begin{array}{c}\text { Scale } \\
\text { Factor } \\
(6)\end{array}$} & \multicolumn{2}{|c|}{$\begin{array}{l}\text { Increase in } \\
\text { NPF }\end{array}$} & \multicolumn{3}{|c|}{ Stressed NPF } \\
\hline & & & & & & & \multirow{2}{*}{$\begin{array}{c}\text { Short } \\
\text { Term }\end{array}$} & \multirow{2}{*}{$\begin{array}{c}\text { Long } \\
\text { Term }\end{array}$} & \multirow{2}{*}{$\begin{array}{c}\text { Level } \\
(9)\end{array}$} & \multicolumn{2}{|c|}{$\begin{array}{c}\text { Time } \\
\text { Increase }\end{array}$} \\
\hline & & & & & & & & & & $(10)$ & $(11)$ \\
\hline $\begin{array}{l}\text { Pertanian, kehutanan dan sarana } \\
\text { pertanian }\end{array}$ & 4,91 & 4,18 & 0,62 & 0,08 & 0,22 & 0,047 & 0,04 & 0,10 & 4,28 & 1,03 & 0,87 \\
\hline Pertambangan & 6,26 & 8,75 & 0,71 & 0,24 & 0,83 & 0,059 & 0,14 & 0,49 & 9,24 & 1,06 & 1,48 \\
\hline Perindustrian & 6,40 & 6,76 & 0,84 & 0,02 & 0,12 & 0,060 & 0,01 & 0,07 & 6,84 & 1,01 & 1,07 \\
\hline Listrik, gas dan air & 3,38 & 11,10 & 0,82 & 0,13 & 0,74 & 0,033 & 0,04 & 0,24 & 11,34 & 1,02 & 3,36 \\
\hline Konstruksi & 6,34 & 3,51 & 0,73 & 0,05 & 0,20 & 0,059 & 0,03 & 0,12 & 3,63 & 1,03 & 0,57 \\
\hline Perdagangan, restoran dan hotel & 6,61 & 6,66 & 0,72 & $-0,01$ & $-0,03$ & 0,062 & $-0,01$ & $-0,02$ & 6,64 & 1,00 & 1,01 \\
\hline $\begin{array}{l}\text { Pengangkutan, pergudangan dan } \\
\text { komunikasi }\end{array}$ & 7,22 & 5,17 & 0,59 & $-0,04$ & $-0,11$ & 0,067 & $-0,03$ & $-0,07$ & 5,10 & 0,99 & 0,71 \\
\hline Jasa dunia usaha & 3,04 & 4,60 & 0,65 & $-0,02$ & $-0,06$ & 0,029 & $-0,01$ & $-0,02$ & 4,58 & 1,00 & 1,51 \\
\hline Jasa sosial/masyarakat & 4,31 & 4,92 & 0,81 & 0,06 & 0,30 & 0,041 & 0,02 & 0,12 & 5,04 & 1,03 & 1,17 \\
\hline Total & 4,35 & 5,85 & 0,83 & 0,03 & 0,18 & 0,042 & 0,01 & 0,08 & 5,92 & 1,01 & 1,36 \\
\hline
\end{tabular}

Sumber: Hasil Estimasi. 
risiko kredit yang digunakan adalah NPL, sedangkan untuk perbankan syariah adalah NPF. Sementara variabel makro eksogenus yang digunakan adalah PDB riil, kurs (Rupiah per USD), Indeks Harga Konsumen (IHK), dan Tingkat Suku Bunga (BI Rate). Spesifikasi model yang digunakan adalah ARDL. Pemilihan model ini didasari oleh kemampuan model tersebut yang dapat menangkap efek jangka pendek dan jangka panjang dari variabel makro eksogenus terhadap risiko kredit (NPL dan NPF). Dengan menggunakan kerangka model tersebut, estimasi dilakukan untuk setiap tipe kredit yang diklasifikasikan berdasarkan 9 (sembilan) sektor dan total seluruh sektor. Dengan demikian, akan terdapat 20 hasil estimasi model yang berbeda, yang terdiri dari 10 model risiko kredit perbankan konvensional (NPL) dan 10 model risiko kredit perbankan syariah (NPF).

Secara umum, studi ini menemukan adanya kemiripan efek dari variabel makro eksogenus terhadap variabel risiko kredit pada kedua kelompok bank. Meski dengan magnitude yang bervariasi, ditemui penurunan PDB, depresiasi kurs, kenaikan IHK (inflasi) dan kenaikan tingkat suku bunga (BI Rate) berkontribusi dalam mendorong kenaikan level NPL maupun NPF. Di sini ditemui bahwa kenaikan IHK (inflasi) merupakan sumber kerentanan terbesar bagi risiko kredit pada kedua kelompok bank, diikuti oleh PDB, kurs, dan tingkat suku bunga (BI Rate). Fakta ini mengindikasikan bahwa kerentanan sistem keuangan pada kedua kelompok bank tidak hanya bergantung pada kinerja internal pada setiap bank, namun juga dinamika makro eksternal. Dengan kata lain, hasil ini mengkonfirmasi bahwa meski bank syariah dan bank konvensional menggunakan sistem operasi yang berbeda, namun keduanya tidak terlepas dari dinamika ekonomi makro yang terjadi. Mengingat strategisnya peran perbankan dalam menunjang pelaksanaan pembangunan ekonomi nasional, maka temuan ini merupakan pesan kuat bagi para pemangku kebijakan akan pentingnya menjaga stabilitas fundamental ekonomi makro nasional. Dengan demikian, tingkat inflasi, nilai tukar, pertumbuhan ekonomi dapat terus terjaga di masa mendatang.

Selanjutnya, meski data aktual sepanjang periode observasi (Januari 2009-Desember 2016) menunjukkan level dan volatilitas NPF secara ratarata lebih tinggi dari level NPL, namun studi ini menemukan bahwa NPL relatif lebih rentan terhadap guncangan makro daripada NPF. Fenomena ini ditemui terutama pada kasus guncangan PDB, IHK (Inflasi), dan kurs. Hal ini terlihat dari level kenaikan NPL dari posisi periode akhir observasi dan posisi rata-rata yang relatif lebih tinggi dari level kenaikan NPF. Level kenaikan ini tidak hanya terjadi menurut tipe kredit, namun juga secara agregat, baik dalam jangka pendek maupun jangka panjang. Hasil ini merupakan indikasi bahwa variabel makro eksogenus bukan merupakan satu-satunya determinan fluktuasi NPF. Hal ini merupakan konsekuensi dari masih relatif kecilnya size dan relatif tingginya cost of fund dari perbankan syariah. Kedua faktor tersebut berimplikasi pada terbatasnya sumber pembiayaan perbankan syariah pada sektor-sektor ekonomi yang lebih luas. Sehingga pengaruh makro ekonomi terhadap NPF menjadi tidak sebesar terhadap NPL.

Fakta ini tentunya juga merupakan pesan yang kuat bagi para pelaku usaha di sektor perbankan syariah agar terus melakukan perbaikan secara internal. Beberapa di antaranya seperti mencari strategi yang tepat untuk memperluas pencarian dana murah masyarakat dalam upaya mengurangi cost of fund, serta melakukan diversifikasi aset dalam upaya meminimalisir pengeluaran operasional.

\section{DAFTAR PUSTAKA}

\section{Jurnal}

Beik, I. S., dan Arsyianti, L. D. (2008). Why the rate of financing in Islamic Banks is high? An analysis based on Malaysian case. Tazkia Islamic Finance and Busssiness Review, 3(1): 18-29.

Elsiefy, E. (2012). Stress test for islamic and conventional banks using sensitivity scenario test: Evidence from Qatari Banking Sector. International Journal of Economics and Management Sciences, 1(12): 44-63.

Foglia, A. (2009). Stress testing credit risk: A survey of authorities approaches, banking and financial supervision, Bank of Italy. International Journal of Central Banking, 5(3): 9-45.

Froyland, E., dan Larsen, K. (2002) How vulnerable are financial institutions to macroeconomic changes? An analysis based on stress testing. Economic Bulletin, 3(11): 127-169.

Husa, P. P., dan Trinarningsih, W. (2015). Credit risk in Indonesia: Islamic Bank vs Conventional Bank. Jurnal Manajemen dan Kewirausahaan, 13(1): 53-60.

Kaminsky, G.L, dan Reinhart, C.M. (1999).The twin crises: The causes of banking and balance of payments problems. American Economic Review, 89(3): 473-500. 
Pesaran, M. H., Shin, Y., dan Smith, R. (2001). Bounds testing approaches to the analysis of level relationships. Journal of Applied Econometrics, 16, pp. 289-326.

Nursechafia dan Abduh, M. (2014). The susceptibility of Islamic Banks' credit risk towards macroeconomic variables. Journal of Islamic Finance, 3(1): 023-037.

Vazquez, F., Tabak, B. M., dan Souto, M. (2012). A macro stress test model of credit risk for the Brazilian Banking Sector. Journal of Financial Stability, 8(2): 69-83.

\section{Sumber Digital}

Misina, M. dan Tessier, D. (2008). Non-linearities, model uncertainty and macro stress testing. Bank of Canada Working Paper 2008-30. Available at: http://www.bankofcanada.ca/wpcontent/ uploads/2010/02/wp08-30.pdf

Oviedo, P. (2003). Macroeconomic risk and banking crises in emerging market countries: Business fluctuations with financial crashes. Manuscript. Available at: https://pdfs.semanticscholar.org/ b064/7d71219681b07313c9b388f5719570a 7e147.pdf

\section{Laporan Pemerintah}

Bank Indonesia.(1999,2012). Annual economic report on Indonesia. Various Issues. Jakarta, Indonesia.

\section{Sumber Lain}

Głogowski, A. (2008). Macroeconomic determinants of Polish Banks' loan losses -Results of a panel data study. National Bank of Poland Working Paper No. 53.

Hoggarth, G., Sorensen, S., dan Zicchino, L. (2005). Stress tests of UK Banks using a VAR approach. Bank of England Working Paper No. 282.

Jones, M., Hilbers, P., dan Slack. (2004). Stress testing financial systems: What to do when the governor calls. IFM Working Paper No.127.

Kattai, R. (2010). Credit risk model for the Estonian banking sector. Bank of Estonia Working Paper No. $1 / 2010$.

Pesaran, M. H., dan Shin, Y. (1999). An autoregressive distributed lag modelling approach to cointegration analysis, in Strom, S. (Ed.). Paper presented at Econometrics and Economics Theory in the 20th Century: The Ragnar Frisch Centennial Symposium, Cambridge University Press, Cambridge.

Otani, A., Shiratsuka, S., Tsurui, R., dan Yamada, T. (2009). Macro stress-testing on loan portfolio of Japanese Banks. Bank of Japan Working Paper Series No. 09-E-1. 